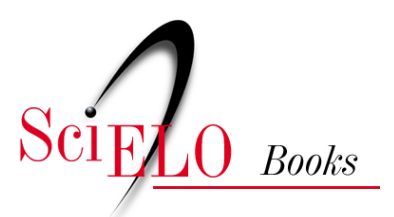

\title{
No palco como num quadro
}

\author{
Eduardo Tudella
}

\section{SciELO Books / SciELO Livros / SciELO Libros}

TUDELLA, E. No palco como num quadro. In: A luz na gênese do espetáculo [online]. Salvador: EDUFBA, 2017, pp. 313-352. ISBN: 978-85-232-1858-4.

https://doi.org/10.7476/9788523218584.0011.

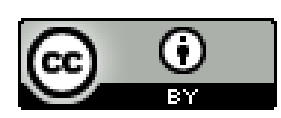

All the contents of this work, except where otherwise noted, is licensed under a Creative Commons Attribution $\underline{4.0 \text { International license. }}$

Todo o conteúdo deste trabalho, exceto quando houver ressalva, é publicado sob a licença Creative Commons Atribição 4.0.

Todo el contenido de esta obra, excepto donde se indique lo contrario, está bajo licencia de la licencia Creative Commons Reconocimento 4.0. 


\title{
NO PALCO COMO NUM QUADRO
}

\begin{abstract}
A flagrante visualidade da práxis cênica interage com o pensamento do século XVIII que define o espetáculo como uma imagem, ou melhor, como uma sucessão de imagens vivas. Tratando da unidade de ação, já aqui discutida, D’Aubignac (1715, p. 72, tradução nossa) diz: "O Palco, certamente, nada mais é que uma imagem [...]". Sua abordagem teórica da representação teatral do século XVII projeta a cena como uma manifestação visual e estabelece relações de simbiose entre imagem e cena, assegurando para os aspectos visuais papéis determinantes no espetáculo. Ainda que ele tenha deixado brechas para a desqualificação parcial da sua abordagem ao defender com veemência as unidades de ação e de lugar, seu trabalho é relevante para a exemplificação da atitude de artistas e teóricos que aplicam a visualidade como instrumento, caminho e/ou estratégia para fundamentar suas convicções teatrais.
\end{abstract}

1 “Il est certain que le Théâtre n'est rien qu'une Image [...]." 
O estudioso francês Jean-Jacques Roubine traz o texto de Jean Chapelain (1585-1674), escrito em 1630, para demonstrar o realismo ali anunciado: "Coloco como fundamento que a imitação em qualquer poema deve ser tão perfeita que nenhuma diferença transpareça entre a coisa imitada e a que imita". (CHAPELAIN apud ROUBINE, 2003, p. 29) Num determinado momento do século XVIII, a práxis cênica tornou-se um encontro que fazia interagir a dramaturgia e o desejo de imitação da realidade expresso pela imagem. Denis Diderot (1713-1784) usa a pintura como referência, mas alerta o responsável pela cena para que ele se afaste dos equívocos cometidos pelos pintores:

Se, ao invés de permanecer entre as personagens e deixar ao espectador suas próprias escolhas, o poeta sair da ação e descer para a plateia, ele interferirá no seu plano. Ele imitará os pintores que, em vez de se concentrarem na rigorosa representação da natureza, a perdem de vista, para se ocuparem dos recursos da arte, e pensam, não em mostrar a natureza como ela é, e como eles a veem, mas em subordinar sua representação aos meios técnicos e comuns. ${ }^{2}$ (DIDEROT, 1875, p. 373-374, tradução nossa)

Para comentar tal vertente, é preciso trazer à discussão trabalhos de outros estudiosos, dada a relevância de determinadas reflexões teóricas para a discussão da luz na sua condição de componente da cena. O século XVIII incorpora o fortalecimento da abordagem científica que, já vislumbrada na Renascença, ganhou abrangência na investigação praticada no século XVII. A arte interage com o movimento em direção ao trato científico da experimentação do mundo, que pode ser representado pelo legado de alguns estudiosos, como a publicação de Isaac Newton (1642-1727), Princípios matemáticos da filosofia natural (Philosophiae naturalis principia mathemática, 1686), obra considerada de grande importância para o estudo dos princípios da ciência. O progresso científico encaminhado pelo pensamento iluminista interagiu com mudanças no contexto político-social, o que encetou discussões no caminho do pensamento democrático moderno e provocou como movimento decisivo a Revolução Francesa (1789-1799).

A trajetória que se instala desde o empirismo de Francis Bacon (1561-1626), o racionalismo moderno da abordagem de René Descartes (1596-1650), passando

2 “ $\mathrm{Si}$, au lieu de se renfermer entre les personnages et de laisser le spectateur devenir ce qu'il voudra, le poëte sort de l'action et descend dans le parterre, il son plan. Il imitera les peintres, qui, au lieu de s'attacher à la représentation rigoureuse de la nature, la perdent de vue pour s'occuper des ressources de l'art, et songent, non pas à me la montrer comme elle est et comme ils la voient, mais à en disposer relativement à des moyens techniques et comuns." 
por Isaac Newton e John Locke (1632-1704), demonstra a contribuição das reflexões de pensadores ingleses e franceses ao conjunto de ações que tornaram o século XVIII conhecido como o Siècle des lumières, na França. O idioma inglês refere-se a Enlightenment e, em alemão, aparece no célebre texto de Immanuel Kant (1724-1804) Was ist aufklärung? (1784). Então, já no último quarto do século, Kant usa uma expressão mais abrangente que pode ser compreendida como esclarecimento. É importante registrar que, tanto em francês quanto em inglês, e até no vocábulo português "Iluminismo" é notável o modo otimista - já bastante estudado pelos mais diversos campos do conhecimento - de se colocar diante da vida, ligando a luz aos pressupostos do progresso científico, social, filosófico e artístico.

Se a excelência da luz esteve ligada a instâncias divinas, instaladas além do alcance humano, iluminando-o de modo absoluto, ideal, desde então, a humanidade passou a entender-se capaz de também iluminar suas próprias relações, através do esclarecimento, da dedução racional e da indução empirista, da luz da razão. A instância material que daí decorre indica uma busca que se refere a pressupostos negados pelo chamado Ancien régime (Antigo regime), nos moldes da Escolástica, criticada pelos iluministas por representar o caminho para um conhecimento dependente de dogmas religiosos e sem a sustentação da racionalidade natural.

Sem intentar aprofundamentos particulares, serão destacados aqui aspectos que podem contribuir para a presente investigação, principalmente quando se considera o movimento teórico orientado pelos estudos da retórica, que estabeleceram elos não apenas entre a oratória e a estética, mas também entre oratória e música, repercutindo nas artes visuais. Tal proposição acabou por se expandir e alcançar o ofício do ator, cuja excelência apontava para o gesto inspirado na pintura e na escultura. É importante mencionar certas iniciativas, inscritas tanto em investigações teóricas, quanto na poética de alguns artistas do século em questão, uma vez que são determinantes para a visualidade da cena.

O presente capítulo observa, por conseguinte, documentos que constituem bases para a compreensão da interação dinâmica entre a visualidade e a práxis cênica, reconhecendo a necessidade de pontuar traços que resultam de tal interação e podem ser observados nas atividades de artistas, comentadores e críticos, em momentos particulares do período denominado Iluminismo. Considere-se a possibilidade de estudar a luz como um componente do espetáculo, cuja atuação efetiva seu discurso poético-visual, fazendo cair por terra a abordagem limitada que estabelece vínculos exclusivamente técnicos-operacionais para a luz 
na práxis cênica e/ou trata de maneira apenas superficial a trajetória estética da imagem cênica.

Desde o teatro da Grécia clássica, a cena esteve comprometida com a expressão visual. O espaço dos teatros gregos interagia de modo inevitável com a luz natural, com a aproximação do pôr do sol, elaborando o discurso visual através da recriação da majestosa arquitetura em gigantescas sombras projetadas sobre a cena e até sobre os espectadores, criando uma visualidade grandiosa. Pode-se dizer que se algum elemento do teatro grego se mantinha em movimento constante, somente a sombra, projetada sobre o espaço cênico em relação direta com o movimento do sol, tinha tal privilégio. As assertivas visuais na espetacularidade medieval não pouparam esforços para incorporar a luz divina à cena. E a celebração renascentista da centralização no humano confiava na eficiência do controle visual do mundo, afirmada na sua observação e representação monocular controlada e calculada.

Na França dos séculos XVII e XVIII, os artistas tiveram a companhia de teóricos, ou se apresentaram também como teóricos, registrando suas preocupações com a natureza visual da práxis cênica. Ao final da primeira metade do século XVIII, depois de várias décadas de experiências apresentadas pelo empreendimento teatral francês, ao escrever a introdução da sua tragédia Semiramis (1748), Jean-François Arouet $^{3}$ (1694-1778) critica severamente a configuração espacial e a qualidade visual do teatro francês do seu período:

Um teatro construído de acordo com as regras [artísticas] deve ser um amplo edifício; nele deve ser possível representar uma praça pública, o peristilo de um palácio, a entrada de um templo. Ele deve permitir que uma personagem vista pelo público possa estar supostamente invisível para outras personagens em cena, de acordo com as necessidades de uma peça. Ele deve agradar aos olhos, em primeiro lugar. Deve ser capaz de apresentar a mais majestosa pompa. Todos os espectadores devem ouvir e ver igualmente bem, de qualquer lugar da plateia. Como se pode esperar tudo isso de um teatro estreito, em meio a tantos jovens [sentados nas laterais do palco], o que deixa tão pouco espaço para os atores desempenharem seus papéis. Devido a isso, a maioria das peças não representa mais do que extensas

3 Nome de registro de Voltaire. Algumas prováveis razões são apresentadas por estudiosos para que ele tenha assumido o nome: uma delas indica a inspiração numa propriedade da sua família, um castelo chamado Airvaut. Outros pensam que ele pode ter usado um anagrama da latinização do seu sobrenome que geraria Arovet Li. Acredita-se também que ele decide tomar o nome Voltaire, depois de ser preso na Bastilha, e cortar relações com seu passado, o que estabelece uma separação formal da família. 
conversas: toda a ação dramática é frequentemente perdida ou representada de modo ridículo. Esse abuso ainda subsiste porque foi estabelecido antes e, pelo mesmo motivo que as pessoas não derrubam suas casas, ainda sabendo que elas foram mal construídas. O abuso público raramente é corrigido até que se alcancem extremas proporções. De resto, quando falo de uma ação teatral, me refiro a um dispositivo, a uma cerimônia, a um conjunto; a um acontecimento necessário à peça; e não a esses espetáculos vazios, com mais imaturidade que pompa, recursos dos cenógrafos que solucionam [escamoteiam] a esterilidade do poeta e que divertem aos olhos, sem falar aos ouvidos ou à alma. ${ }^{4}$ (AROUET, 1761, p. 152, tradução nossa)

Voltaire clamava pela unidade de um espetáculo no qual os diversos aspectos interajam, num conjunto (assemblée) de contribuições artísticas, jogando positivamente para criar uma única obra. Por outro lado, no prefácio da sua tragédia Les scythes (ou saces), ${ }^{5}$ representada em março de 1767, ele diz: "É nessa grande arte de falar aos olhos que brilha o maior ator que a Inglaterra já teve, Mr. Garrick, que assombrou e tocou a todos nós, mesmo aqueles que não sabiam sua língua”. (AROUET, 1835, p. 50, tradução nossa) Ele se refere a David Garrick (1717-1779), ator inglês, cuja parceria com o cenógrafo Phillipe de Loutherburg (1746-1812) deixou significativo legado para a história da visualidade do teatro. Não se pode dizer, de modo simplório, que a declaração de Voltaire represente uma contradição, pois a grande arte de falar aos olhos está intimamente ligada àquela que "fala à alma", uma vez que não se trata de isolar um sentido, mas de reconhecer a relevância da visualidade no teatro.

\footnotetext{
4 "Un théâtre construit selon les règles tout être très vaste; il doit représenter une partie d'une place publique, le péristyle d'un palais, l'entrée d'un temple. II doit être fait de sorte qu'un personnage vie par les spectateurs, puisse ne l'être point par les autres personnages selon le besoin. II doit en imposer aux yeux qu'il faut toujours séduire les premiers. Il doit être susceptible de la pompe la plus majestueuse. Tous les spectateurs doivent voir \& entendre également, en quelque endroit qu'ils soient placés. Comment cela peut-il s'exécuter sur une scène étroite au milieu d'un foule de jeunes gens qui laissent à peine dix pieds de place aux acteurs? De là vient que la plupart des pièces ne sont que de longues conversations; tout action théâtrale est souvent manquée \& ridicule. Cet abus subsiste comme tant d'autres, par la raison qu'il est établi, \& parce qu'on jette rarement sa maison par terre quoi qu'on sache qu'elle est mal tournée. Un abus public n'est jamais corrigé qu'à la dernière extrémité. Au reste, quand je parle d'une action théâtrale, je parle d'un appareil, d'une cérémonie, d'une assemblée, d'un événement nécessaire à la pièce ; \& non pas de ces vains spectacles plus puériles que pompeux, de ces ressources du décorateur qui suppléent à la stérilité du poète, \& qui amusent les yeux, quand on ne fait pas parler aux oreilles \& à l'âme."

5 Em grego antigo $\Sigma \kappa v ̉ \theta \alpha 1$, Skútha; um grupo de povos nômades de origem indo-europeia, que ocupou regiões como as estepes eurasianas até por volta do século III.

6 'C'est dans ce grand art de parler aux yeux qu'excelle le plus grand acteur qu'ait jamais en Anglaterre, M. Garrick qui a effrayé et attendri parmi nous ceux même qui ne savaient pas sa langue."
} 
Em 1781, Antoine Lavoisier (1743-1794) abre seu Relato sobre a iluminação de casas de espetáculo (La Mémoire sur manière d'eclairer les salles de spectacle), cujo título já desperta interesse, uma vez que ele destaca a iluminação dos teatros e também dos espetáculos no século XVIII como objetos de estudo. Lavoisier criticou severamente o espaço teatral da sua época, na França. Em sua opinião, de vários pontos da plateia, o público não podia ver, tampouco ouvir de modo correto, o que acontecia no palco. Segundo ele, tanto em Paris quanto nas principais cidades francesas, as casas de espetáculo eram construídas em espaços alongados como quadras de jogos, um tipo de edifício inadequado que nem sequer podia ser denominado teatro.

Consultando-se os desenhos que representam a Salle de machines, como era denominado o teatro instalado nas Tulherias, é possível considerar equivocadas proporções de largura e profundidade, repercutindo nos ângulos de visão do espectador (Figura 85). No que se refere à luz, Lavoisier (1781, p. 409, tradução nossa) resume: "O modo como se ilumina o espetáculo e os espectadores corresponde a essa espécie de estado de barbárie".7

A observação do termo barbárie é importante para a compreensão do seu ponto de vista. Ele critica duramente o incômodo causado aos espectadores durante o processo de reparo das velas, assim como aquele gerado pelos candelabros, cujo posicionamento impedia que o público acomodado nos balcões superiores tivesse pleno acesso visual ao espetáculo. Lavoisier aponta mudanças importantes ocorridas no período, como a substituição das velas de sebo por outras de cera e por lamparinas, que representaram menor desconforto, quando comparadas ao mau odor produzido pelas primeiras velas citadas.

A unificação da luz da plateia em um único candelabro tornou a iluminação mais suave, ou seja, corrigindo a ofuscação dos espectadores. Lavoisier (1781) aponta, contudo, graves problemas, tais como a impossibilidade de iluminar satisfatoriamente a plateia com um candelabro, tornando impossível reconhecer pessoas sentadas à média distância. O candelabro também não permitia a leitura de libretos para acompanhar os atores, atividade que Lavoisier considerava muito importante para o desenvolvimento do gosto e da educação literária dos jovens; além disso, a luz de ribalta era demasiado intensa, a ponto de prejudicar a visão dos espectadores sentados mais próximos do limite do palco.

Apoiado no seu próprio trabalho sobre a iluminação das ruas, ele apresenta indicações para o teatro:

7 “La manière d'éclairer le spectacle et les spectateurs répondait à cette espèce d'état de barbarie." 
Três objetivos devem ser efetivados quando se pretende iluminar um teatro: iluminar o palco e os cenários, iluminar o ator e iluminar o espectador. | O modo de iluminar o palco e os cenários por meio de lampiões adaptados aos elementos cenográficos [tapadeiras], de modo que a luz instalada numa tapadeira ilumine aquela que está imediatamente atrás dessa primeira, e assim sucessivamente até o fundo do palco, não está sujeito a qualquer objeção; acredito que poderíamos fazer uma considerável economia de combustível, adaptando a esses lampiões, como já se tentou fazer, refletores [réverbères] ${ }^{8}$ móveis e bem executados, de modo que se possa direcionar a luz refletida para onde for necessário; isso resultaria numa recuperação de grande parte da luz que se perde no modo como hoje se opera. ${ }^{9}$ (LAVOISIER, 1781, p. 411, tradução nossa)

Lavoisier comenta várias questões ainda hoje inerentes aos espetáculos, deixando um testemunho vivo da relevância dos processos que envolvem a aplicação da luz na práxis cênica, desde aspectos de natureza econômica até aqueles que se referem a pressupostos estéticos. Ele aponta, entre outras coisas, soluções para iluminar os telões de fundo, buscando corrigir um defeito que parecia recorrente no tratamento desses elementos e que considerava decisivo para a constituição do espaço da cena: a parte central dos telões de fundo apresentava deficiência na sua visibilidade durante os espetáculos, uma vez que o sistema de luzes laterais não a iluminava corretamente. Lavoisier, então, indicou a aplicação de lanternas, luminárias ou lampiões que, instalados numa vara acima do palco e incluindo refletores móveis permitiriam dirigir a luz para o ponto desejado, alcançando o brilho que ele exigia para a cena:

Essa parte do palco [do cenário], sempre vista de frente e que representa as perspectivas e as distâncias, é uma das mais importantes no que se refere à ilusão que se deve produzir no espectador: é necessário, portanto, que se possa iluminá-la com maior

\footnotetext{
8 Como são conhecidos os postes aplicados na iluminação pública, cuja denominação pode ter derivado da função de reflexão da luz, possibilitada por esses artefatos, também adaptados aos instrumentos da luz teatral.

9 "Trois objets sont à remplir pour éclairer une salle de spectacle: éclairer le théâtre et les décorations, éclairer l'acteur, éclairer le spectateur. La manière d'éclairer le théâtre et les décorations par le moyen de lampions adaptés aux feuilles des décorations, de façon que celle de devant éclaire celle qui est immédiatement derrière elle, et ainsi successivement jusqu'au fond du théâtre, n'est susceptible d'aucun inconvénient; je crois seulement qu'on pourrait faire une économie assez considérable de combustible, en adaptant à ces lampions, comme on a déjà essayé de le faire, des réverbères bien faits et mobiles, de manière qu'on pût diriger la lumière réfléchie dans les parties où on la jugerait nécessaire; on profiterait ainsi d'une portion considérable de lumière qui se perd dans l'état actuel."
} 
ou menor intensidade, tanto quanto se queira, e não há outra maneira para representar com verdade os diversos momentos do dia, o calor do sol, a luz sombria de uma tormenta ou de uma tempestade, um nascer ou um pôr do sol, uma noite, um clarão da lua [...]..$^{10}$ (LAVOISIER, 1781, p. 413, tradução nossa)

Considerações dessa natureza podem contribuir para a compreensão da expectativa de contribuição da luz nos espetáculos, que inclui, na abordagem de Lavoisier, a ilusão e o controle, incorporando aí duas vertentes, a técnica e a estética.

Além disso, sua demonstração da necessidade de iluminar a plateia pode ser equivocadamente apreendida, como se representasse uma desvantagem para a função da luz no espetáculo. Vale ressaltar suas assertivas, pois elas confirmam a importância da luz para o contexto por ele descrito e reiteram a contundência das marcas dessa mesma luz na estética em questão. Ele tratava, por um lado, de níveis particulares da contribuição social do teatro, ao considerar imprescindível a boa iluminação da plateia, tanto para o contato entre os espectadores quanto para a formação dos jovens. Por outro, Lavoisier fez incursões de natureza técnica ao estabelecer relações diretas com a proposição estética do teatro. Se o cenário deve ser iluminado de modo a expressar determinada atmosfera, incluindo a aplicação de cores, ao ator deveria ser dispensada maior atenção, de acordo com suas justificativas: "é ele [o ator] que anima a cena, é através dele que o sentimento alcança a alma do espectador; o menor movimento, a menor alteração nas suas expressões, tudo deve ser sentido, nada deve ser evitado [...]".11 (LAVOISIER, 1781, p. 413, tradução nossa)

Do ponto de vista da estética que apoia o espetáculo vislumbrado por Lavoisier, a ilusão de realidade é imprescindível. E, sem a aplicação precisa da luz, o objetivo estético não seria alcançado. Os diversos aspectos da cena - a dramaturgia, a cenografia, a interpretação e a luz - deveriam interagir na sua realização.

Outro autor cujo pensamento alcança grande relevância no debate acerca do teatro francês do século XVIII é Denis Diderot, já citado anteriormente. Ele propõe uma abordagem visual do espetáculo, solicitando do dramaturgo olhar constante

\footnotetext{
10 "Cette partie du théâtre qui est toujours vue de face, et qui représente des perspectives et des lointains, est une des plus importantes, relativement à l'illusion qu'elle doit produire sur les spectateurs ; il est donc nécessaire qu'on puisse l'éclairer plus ou moins à volonté, et ce ne sera que par ce moyen qu'on pourra rendre avec vérité les divers instants du jour, l'ardeur du soleil, la lumière sombre d'un orage ou d'une tempête, un lever ou un coucher du soleil, une nuit, un clair de lune, [...]."

11 "cést lui qui anime la scène, c'est par lui que le sentiment passe dans I'âme du spectateur: le moindre mouvement, la moindre altération dans ces traits, tout doit être sènti, rien ne doit échapper [...]."
} 
e atento à cena, o que resultaria em um modo particular de escrita teatral. Diderot reage a um teatro ocupado pela imitação empoada da Antiguidade e/ou interessado por lugares distantes e exóticos, resultando numa ficção deslocada da experiência cotidiana.

Refletindo sobre essa escrita para o teatro, assim como nas suas relações com a práxis cênica, ele escreveu Discussão sobre o Filho natural [Entretiens sur Le fils naturel (1757)] e Da poesia dramática [De la poésie dramatique (1758)], além das peças $O$ filho natural (Le fils naturel) e O pai de família (Le père de famille). Diderot se insurge, importunado pelo teatro do seu tempo que, de modo negativo, impregnaria a rima, os versos alexandrinos, ${ }^{12}$ e critica as convenções cenográficas generalizantes do palais à volonté, e das múltiplas mudanças de cenários (scene à machine); a cena era povoada por atores que se expressavam através de gestos exagerados usando uma indumentária negativamente estilizada:

O que mais mostra, contudo, como ainda estamos longe do bom gosto e da verdade é a pobreza e a falsidade dos cenários, além do luxo dos figurinos. | Vocês exigem que os dramaturgos se ajustem à unidade de lugar, e abandonam a cena à ignorância de maus cenógrafos. ${ }^{13}$ (DIDEROT, 1875, p. 373-374, tradução nossa)

Ele fundamenta suas convicções enfatizando a necessidade de uma compreensão particular da natureza do teatro:

Na sociedade, os eventos não duram mais do que um conjunto de pequenos incidentes, o que daria verdade a um romance, mas que removeria todo o interesse da obra dramática: nossa atenção é capaz de atender a uma infinidade de diferentes objetos: mas, no teatro, onde não se representa mais que instantes particulares da vida real, faz-se necessário que nos concentremos inteiramente na mesma coisa. ${ }^{14}$ (DIDEROT, 1875 , p. 88 , tradução nossa)

\footnotetext{
12 Maurice Grammont (1913) assim definiu: o alexandrino era originalmente um verso silábico composto por dois membros iguais ou hemistíquios separados por uma cesura [pausa]. Cada hemistíquio contava seis sílabas, cuja última era obrigatoriamente acentuada; mas cada uma era susceptível de conter uma sétima sílaba, tendo por vogal um $e$ inacentuado e terminando a palavra que fornecia a sexta sílaba. Essa sétima sílaba não contava no metro e sua pronúncia encontrava lugar na pausa que separava um verso do próximo ou naquele que comportava a cesura. Nenhuma dessas duas pausas poderia ser puramente artificial: a sintaxe as devia exigir ou pelo menos as permitir.

13 "Mais, ce qui montre surtout combien nous sommes encore loin du bon goût et de la vérité, c'est la pauvreté et la fausseté des décorations, et le luxe des habits. | Vous exigez de votre poëte qu'il s'assujettisse à l'unité de lieu; et vous abandonnez la scène à l'ignorance d'un mauvais décorateur."

14 "Dans la société, les affaires ne durent que pas de petits incidents, qui donnerait la verité à um roman, mais qui òteraient tout l'intérêt à un ouvrage dramatique: notre attention s'y partage sur une infinité d'objets différents: mais au théâtre, où l'on ne représente que des instants particuliers de la vie réelle, il faut que nousw soyons tout entiers à la même chose."
} 
Diderot (1875) acreditava em um teatro que deveria eleger seletivamente eventos para se referir à natureza humana. E defendia a unidade de lugar, considerando que a multiplicidade de ocorrências, inclusive mudanças sucessivas de cenários, dificultava a concentração do espectador, julgando difícil - mas importante - a aplicação das três unidades. No núcleo do seu raciocínio teatral estava a crítica a uma convenção dramatúrgica que dava ao autor e ao responsável pelo espetáculo a possibilidade e o direito de "resolver a cena" com procedimentos que ele considerava um artifício teatralmente falso. Em Da poesia dramática, Diderot (1771, p. 147, grifo e tradução nossos) define o procedimento:

O segundo ato da peça começa com um tableau e é concluído com um coup de théâtre. [...] Um incidente inesperado que ocorre na ação e, de repente, muda o estado das personagens, é um coup de théâtre [uma saída brusca, sem justificativa aparente]. Qualquer disposição dessas personagens no palco, se natural e verdadeira, como fielmente representada numa tela por um pintor, me deleitaria; isso é um tableau [quadro]. ${ }^{15}$

O confronto entre tableau e coup de théâtre contribuiu para a teoria do espetáculo encaminhada por Diderot; ao invés de resolver uma cena através de um mecanismo dramatúrgico sem justificativa na ação e denominado coup de théâtre, ele defendia a aplicação do tableau, ou seja, a criação, o desenrolar e a conclusão do espetáculo, através de imagens capazes de compartilhar com o espectador o natural e o verdadeiro. Ele julgava necessária a estreita intimidade dessas imagens com a palavra, na sua condição de componente que contribui para a criação da cena. Na verdade, a escolha do termo tableau - como ele mesmo declarava - ligava drama e pintura, portanto, palavra, ação e imagem. Essa eloquência da imagem, que "fala" de modo eficiente, sugere tangências com a retórica e fornece pistas para localizar provocações que ele teria aceitado, ao construir sua teoria.

Nos estudos de Diderot, o conceito de tableau pode ser vinculado à discutida tipificação espacial originada no teatro italiano da Renascença. E a organização frontal caixa cênica/boca de cena/plateia - que aponta para a convenção da quarta parede (invisível) já disposta na boca de cena, determinando o limite virtual entre realidade e ficção: "Esteja você escrevendo ou representando, pense no espectador, como se ele não existisse. Imagine, na frente da boca de cena, uma grande parede

\footnotetext{
15 “Le second acte de la piéce s'ouvre par un tableau, \& finit par un coup de theatre. [...] Un incident imprévu qui se passe en action \& qui change subitement 1'etat des personnages, est un coup de théâtre. Une disposition de ces personnages sur la scène, si naturelle \& si vraie, que rendue fidelement par un peintre, elle me plairoit sur la toile, est un tableau."
} 
que o separa da plateia; represente como se a cortina não estivesse erguida". ${ }^{6}$ (DIDEROT, 1875, p. 345, tradução nossa) Tal configuração espalhou-se por todo o mundo e foi, por outro lado, exaustivamente criticada como mecanismo ilusionista que tratava o espectador como um membro passivo do jogo teatral, encarcerado numa poltrona, mero voyeur do quadro instalado no interior da caixa-cênica: uma espécie de repercussão da alegoria da caverna de Platão, uma ilusão do real e distância imposta da ideia e da verdade.

Para lidar com a expressão quadro/pintura cênica (tableau dramatique), vale buscar a compreensão do seu uso na obra de Diderot. Romira Worvil117 (2010) observa a aplicação do termo tableau pela crítica francesa numa relação com o termo grego hypotyposis, que, no ambiente da retórica, é assim definida por M. Fabius Quintilianus (35 d.c. - 95 d.c.):

[...] aquilo que pinta as coisas sobre as quais falamos e as coloca diante dos nossos olhos, e isto acontece quando, ao invés de simplesmente relatar um evento, vemos como ele ocorreu, não em generalizações, mas em cada uma das suas circunstâncias particulares. No último livro, tratei desse tema, quando falei da evidência [evidentiae], nome dado a esta figura por Celsus. Ela é denominada por outros hypotyposis e definida por eles como uma representação de coisas em palavras, expressas de tal modo que mais parece uma questão de ver que de ouvir. ${ }^{18}$ (QUINTILIAN, 1774, p. 115, tradução nossa)

Desde abordagens modernas, a hypotyposis ganha maior abrangência, referindo-se à qualidade visual e à vividez da descrição de um evento ou objeto, estabelecendo-se relações com outro termo, agora da retórica grega - a ekphrasis - que define, de modo geral, a estratégia aplicada por um orador para criar a ilusão de realidade; ele alcança tal resultado, empreendendo uma descrição tão vívida que faz o ouvinte se sentir diante da cena, estimulado pela imagem mentalmente elaborada. Criar hypotyposis é fazer ver; ela traz uma contaminação mimética, quando o autor da narração ou descrição torna real (ou cria a ilusão de tornar real)

16 "Soit donc que vous composiez, soit que vous jouiez, ne pensez non plus au spectateur que s'il n'existait pas. Imaginez, sur le bord du théâtre, un grand mur qui vous sépare du parterre; jouez comme si la toile ne se levait pas."

17 Worvill é docente da Acadia University, na Nova Scotia, Canadá.

18 "[...] which paints the things we speak of, and places them, as Cicero says, before our eyes, it happens whenever instead of relating simply a fact, we rather shew how it passed, not in a general way, but in all its particular circumstances. This article in the last book I placed under evidence, the name which Celsus has given to that figure. By others is called hypotyposis and defined by them a representation of things so expressed by words, as to seem rather to be seen, than heard." 
o objeto/evento do processo narrativo ou descritivo. Tais abordagens tanto têm, por um lado, dado lugar a vastos debates quanto, por outro, até se discute a ilusão de real, sem sequer mencionar esses termos. O trabalho em curso, no entanto, incorpora o interesse por esses ângulos muito particulares da questão.

Mencione-se a especulação de Worvill, acentuando que mesmo diante do traço comum entre hypotyposis e ekphrasis, quando ambas se referem ao desejo de fazer o leitor (ou o ouvinte) visualizar na mente o objeto abordado, pode-se observar uma importante diferença: enquanto a primeira buscaria reduzir ou aniquilar a distância entre o leitor e a representação, a segunda introduziria certa rivalidade, ao buscar a autonomia radical da palavra, como que sublinhando uma virtuosidade verbal, exercitando o domínio da palavra que se basta como meio expressivo e de comunicação. Tal diferença importa, uma vez que a presente abordagem investe em parcerias, trocas e negociações, processos nos quais a visualidade se apresenta como aspecto instalador e articulador da manifestação cênica (que ainda hoje pode incluir a manifestação verbal). Daí importa a flexibilidade que reconhece a capacidade da palavra para contribuir na eficiência visual da cena. O movimento inverso torna-se também verdadeiro, uma vez que a visualidade busca interações com a palavra, ou com a ideia que promove o espetáculo.

Tal eficiência já havia sido destacada por Aristóteles, quando ele escreveu:

É necessário arranjar o enredo e completá-lo por meio da elocução, colocando o mais possível, a cena diante dos olhos (pois assim, vendo as coisas o mais possível concretizadas como se estivesse junto aos próprios incidentes, o poeta encontraria o que é adequado e escapar-lhe-ia minimamente o que há de contraditório [...]. (ARISTÓTELES apud GAZONI, 2006, p. 99-100)

A tradução de Gazoni evidencia, para a tarefa do poeta, a importância de ver - com os olhos da mente - a ação acerca da qual se dispõe a escrever; o impacto da palavra no leitor, ou no espectador, era considerado uma qualificação importante para o sucesso da poesia dramática. Observe-se a seguir a tradução inglesa de Gerald F. Else ${ }^{19}$ do mesmo trecho, para destacar o termo vividly, cuja compreensão é muito relevante para a discussão do assunto:

[... ] na construção do mito e na sua apresentação em linguagem verbal, o autor deve por a trama diante do olhar, tanto quanto possível. Dessa forma, vendo mais vívidamente, como

19 Gerald Frank Else (1908-1982), estudioso da Antiguidade clássica, foi professor de latim e grego nas universidades de Michigan e lowa. 
se estivesse realmente perto dos eventos | como eles estivessem acontecendo, o poeta pode conceber a adequada 'estratégia', e as discrepâncias estarão menos propensas a escapar de sua observação. ${ }^{20}$ (ARISTÓTELES, 1983, p. 47, tradução nossa)

Tanto Else quanto Gazoni, portanto, corroboram a importância do "ver diante dos olhos", para o ofício do poeta. As traduções do trecho que se segue, "[...] indicam que o autor deve colocar a trama diante dos seus próprios olhos [...]". ${ }^{21} \mathrm{Tal}$ capacidade e/ou estratégia garantiria, de acordo com a tradução de Else, maior vividez (seing most vividly), como se o autor estivesse diante daquilo que é descrito e garantindo que suas palavras fossem também capazes de provocar vívidas imagens mentais, emprestando, portanto, eficiência à sua poesia dramática. A particularidade dessa tradução inglesa é a presença do termo "vividamente", derivado da pala-

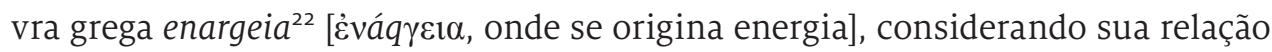
com a visualidade. A compreensão de Aristóteles, assim como de outros estudiosos da poesia e da retórica antigas, incorpora à palavra a capacidade de afirmar-se visualmente. Também para Diderot, a visão imaginativa do dramaturgo é decisiva:

Essas imagens, criadas de acordo com as personagens, afetarão também os discursos e o movimento da cena, sobretudo se o poeta as evoca, as vê, as projeta diante de si mesmo e observa suas mudanças. | [...] não concebo como o dramaturgo pode começar [a escrever] uma cena sem imaginar a ação e o movimento da personagem que ele introduz. ${ }^{23}$ (DIDEROT, 1875, p. 360, tradução nossa)

No seu artigo sobre a crítica poética da Antiguidade, Graham Zanker ${ }^{24}$ apresenta comentários de Dionysius de Halicarnassus (ca. 60 a.c. - 7 a.c.), acerca da obra de Lysias (ca. 445 a.c. - 380 a.c.) e, ainda que muitos estudiosos concordem que enargeia é uma palavra de difícil tradução, Zanker compreende que é possí-

20 [...] in constructing one's plot and working them out in language, one should put them directly before one's eye as much as possible. That way, seeing most vividly, as if he were actually betting close to the events | as they happen, the poet can devise the appropriate 'business', and discrepancies are least likely to escape his notice.

21 "[...] put them directly before one's eye [...]."

22 De acordo com o Oxford Advanced Learner's Dictionary a raiz etmológica do substantivo energia, sendo em (dentro), no interior e ergon (trabalho), atividade. Estudiosos concordam que enargeia é uma palavra de difícil tradução.

23 “Ces images, formées d'après les caractères, influeront aussi sur les discours et sur le mouvement de la scène; surtout si le poëte les évoque, les voit, les arrête devant lui, et en remarque les changements. | [...] je ne conçois pas comment le poëte peut commence une scène, s'il n'imagine pas l'action et le mouvement du personage qu'il introduit."

24 Graham Zanker é professor da University of Canterbury, especialista em literatura grega. 
vel identificar nos comentários de Dionysius uma definição importante do termo. Aplicando a abordagem particular da crítica literária, Dionysius diz que enargeia se refere a um efeito estilístico no qual a qualidade de uma descrição apresenta forte apelo aos sentidos; além disso, as circunstâncias que acompanham o evento são descritas de modo a gerar forte impacto no leitor ou na audiência, tornando aquele que lê ou ouve a leitura de uma obra, testemunha ocular da coisa descrita. Para Dionysius, portanto, a visão é sentido decisivo para a excelência, no contexto. (ZANKER, 1981, p. 297)

Autores como Homero, Platão e Virgílio têm fragmentos dos seus textos mencionados como exemplos da aplicação ou da presença da enargeia. Já foi mencionada a força do drama de Ésquilo, quando se abordou Agamêmnon. Na tragédia grega, ao relatar horríveis fatos e ações que testemunhou, um mensageiro traz o impacto de um acontecimento, mesmo sem ter tomado parte na ação com a plenitude da dramatis personæ. Ele apenas estava presente, ele viu o ocorrido. Na Medeia, de Eurípedes - comentada em Um presumível ponto de partida, o relato do mensageiro constrói a imagem de horror que decorre do envenenamento de Glauce e é um exemplo de excelência na aplicação da enargeia. Vale acentuar que nem mesmo o distanciamento de alguém que estava "fora" da ação enfraquece a função da cena na tragédia como um todo, graças à maestria de Eurípedes no trato da enargeia. Aliás, é precisamente a sua aplicação que dá força ao encaminhamento da ação dramática.

De acordo com estudiosos, essa qualidade da boa poesia pode estar presente também na retórica, qualificando o trabalho do orador. A abordagem teórica em torno do poder de comunicar e exprimir, do qual a palavra pode ser impregnada, produziu uma vastidão de textos: desde os gregos antigos, repercutindo na cultura latina e alcançando Diderot, depois de deixar profundos traços no século XVII. A particularização inerente a diversas áreas do conhecimento determinou variações do conceito de enargeia, e incorporou termos como ekphrasis e hypotyposis. Em certos casos, os termos parecem estar sendo usados como sinônimos ou, quando menos, como manifestações muito próximas, quase sem limites explícitos.

Toda a enorme quantidade de expressões que derivaram do conceito de enargeia, incluindo os correspondentes latinos - que são identificados desde o século I da nossa era, entre eles, descriptio ${ }^{25}$ - guardam um traço comum: os elos entre a palavra e a imagem mental produzida no interlocutor, ouvinte ou leitor, como

25 Zanker (1981 p. 301) cita a definição de descriptio que aparece no Tratado ad Herenium e se refere a uma exposição vívida das consequências de uma ação que provoca indignação e piedade. 
resultado do mencionado impacto que os coloca diante daquilo que é descrito ou narrado, como pondera Ruth Webb: ${ }^{26}$

Enfatizar a natureza retórica da ekphrasis é também dirigir atenção para os vestígios de oralidade do fenômeno, para o modo como as discussões tanto acerca da ekphrasis quanto da enargeia, assumem interações vivas entre aquele que fala e a plateia, com a linguagem passando como uma carga elétrica entre eles. ${ }^{27}$ (WEBB, 2009, p. 129, tradução nossa)

Mesmo que se possa observar uma acentuação utópica, com certo tom romântico ou ideal na observação de Webb, ela pode tocar o ator ou o artista que se aventura na cena acreditando nessa "carga elétrica", fazendo um movimento diverso daquele que se interessa pelo exclusivo tratamento especulativo teórico.

Retorno a Aristóteles (1983, p. 17) para relembrar a compreensão da tragédia como uma manifestação artística que trata de seres humanos que agem ou, na tradução de Else: "[...] men in action". Aqui podem ser encontradas tangentes entre enargeia, ekphrasis, hypotyposis, e vários outros termos como euidentia, demonstratio, illustratio, repraesentatio e descriptio, todos eles ancorados no apelo visual que se pode emprestar à palavra, e alguns deles relacionados à compreensão aristotélica de tragédia, ou seja: "homens que agem".

Dada a abordagem diferenciada da ação nos diferentes momentos da história da espetacularidade a incorporação da palavra pode ser exercida com maior ou menor contundência; a visualidade, contudo, é conditio sine qua non para a práxis cênica. Por um lado, Diderot testemunhava ainda um teatro no qual a palavra parecia reclamar para si uma espécie de hegemonia. (WORVILL, 2010, p. 15) Por outro, impregnado pela apreensão da palavra como uma manifestação repleta de enargeia, Diderot pode ter experimentado certa angústia, não vendo na cena aquilo que a palavra é capaz de provocar no espectador.

A tragédia grega e a Poética de Aristóteles exerceram grande influência naqueles interessados no teatro durante muitos séculos. A repercussão, em Diderot, de pensadores que o antecederam já pode ser observada quando se leem autores como Bernard Lamy (1640-1715) e de Jean-Baptiste Dubos (1670-1742). Lamy (1679, p. 74, tradução nossa) teria assim comentado o trato retórico: "Os tropos

26 Professora e pesquisadora emérita do Departamento de História, Clássico e Arqueologia da Universidade de Londres/Birkbeck; professora associada do Departamento de Grego da Universidade de Paris X, Nanterre.

27 "To emphasize the rhetorical nature of ekphrasis is also to draw attention to the vestigial orality of the phenomenon, the way in which the discussions of both ekphrasis and enargeia assume live interactions between speaker and audience, with language passing like an electrical charge between them." 
são uma pintura sensível da coisa sobre a qual se fala". ${ }^{28}$ Da obra de Dubos vale destacar Reflexões críticas sobre a poesia e pintura, 1719 (Réflexions critiques sur la poésie et la peinture), na qual se podem observar aspectos que teriam influenciado certas proposições teatrais de Diderot. Dubos manifestou sua cumplicidade com Horácio, ao apresentar a expressão horaciana ut pictura poesis (na pintura como na poesia), anunciando seu interesse pelas relações entre a palavra e a visualidade. Seu modo de acentuar a excelência da poesia de Horácio reafirma a crença na intimidade entre essas duas formas de expressão: “[...] as palavras aplicadas pelo poeta para fazer sua pintura nos revelam as ideias, e essas ideias constroem o quadro, na nossa imaginação [...]”. ${ }^{29}$ (DUBOS, 1733, p. 392, tradução nossa)

Fascinava Dubos a habilidade do poeta que aplica signos artificiais, arbitrários - como ele compreendia as palavras -, para pintar na imaginação do público as ideias que lhe vinham à mente, processo cujo resultado ele denominou quadro (tableau), como uma tela executada por um pintor. Worvill invoca uma transparência do signo, que se poderia notar numa pintura na qual a pincelada se desloca para um plano de relativa invisibilidade, acentuando o objeto, o tema da pintura. (WORVILL, 2010) Somente um observador particularmente interessado na intervenção do pincel, registraria a pincelada. Cabe lembrar a pintura que sensibilizava Dubos àquele tempo, obras daqueles que ele chamou grandes mestres, como Peter Paul Rubens (1577-1640) e Nicolas Poussin (1595-1665), destacando em Poussin a paixão com a qual ele impregnou obras como Os pastores de Arcádia (Et in Arcadia Ego), (Figuras 86 e 87), inspirado pelo trabalho de Virgílio (Publius Vergilius Maro, 70 a.c. - 19 a.c.) em Éclogas (ou Bucólicas), cujo tema já aparece em Hesíodo que aponta Arcádia como a cidade de Pan, o deus com chifres e membros inferiores de bode.

Dubos acreditava que na obra de Poussin, o coup de pinceau (golpe ou toque do pincel, a pincelada) é suplantado pelas paixões que movem a pintura. Abordando a expressão ut pictura poesis - na pintura como na poesia - Dubos discute a excelência de uma poesia na qual a palavra alcance transparência, pintando um quadro (tableau) na tela da imaginação do leitor/observador. Em sua opinião, mais que uma pintura, a poesia é capaz de pintar inúmeros quadros que se sucedem, na extensão de uma única obra, tornando-se mais poderosa na expressão e na comunicação.

\footnotetext{
28 "Les tropes son une peinture sensible de la chose dont on se parle."

29 "les mots dont le poëte se sert pour faire sa peinture réveillent en nous les idées, et ces idées forment ensuite dans notre imagination le tableau [...]."
} 
A argumentação de Dubos pode ser sublinhada em relevantes assertivas: "Pode-se dizer, metaforicamente falando, que o olho está mais perto da alma que o ouvido". A mentalidade que suporta afirmações dessa natureza deixou traços importantes em Diderot.

Dubos confiava na eficiência da pintura como meio de estabelecer empatia com o observador, e acreditava que a poesia teria menor poder de alcance no ser humano, pois a pintura se insinua através da visão. Com isso, ele reafirmava sua crença no poder superior da imagem visual construída materialmente com os instrumentos, materiais e suportes próprios da pintura. Ele até apresenta sua defesa, antecipando algum contestador que argumente em favor da poesia, usando o exemplo de uma tragédia, cuja leitura pode suscitar emoções no ouvinte ou leitor. Mesmo que não discordasse radicalmente, ele pondera que, ao lermos uma tragédia, principalmente se nunca a vimos encenada, não experimentaremos a profundidade das emoções que nos alcançam quando temos sua representação no palco.

Dubos (1733, p. 402, tradução nossa) declara-se, portanto, completamente favorável à montagem como necessária para que o trabalho do dramaturgo se completasse, pois, como ele afirma: “[...] uma tragédia contém um infinito número de tableaux [quadros, imagens]. O pintor que faz uma obra sobre o sacrifício de Ifigênia não nos apresenta na tela mais que um instante da ação". ${ }^{\circ}$ Ele parece estar tratando da Ifigênia (Iphigénie), de Racine, e acrescenta que o dramaturgo põe diante dos nossos olhos diversos momentos da ação. Na compreensão de Dubos (1733), enquanto uma pintura lança um único "ataque" à alma do leitor, o poeta tem a seu favor a apresentação sucessiva e planejada de inúmeros quadros, preparando e desenvolvendo visualmente a trama. E conclui essa parte da sua obra salientando que a tecnologia (l'industrie des hommes) havia municiado o pintor com muitas possibilidades, muitos aspectos que poderiam contribuir para a maior eficiência da sua obra, destacando os vernizes e a tela emoldurada que concentra a atenção; ainda assim, contando com o simples ato de recitar - aquele recitar que é acompanhado de gestos, da declamação, e/ou do canto - a poesia guarda a mencionada capacidade de criar inúmeros e sucessivos quadros em uma obra. (DUBOS, 1733) Vale dizer que a mesma pintura figurativa evocada nessas abordagens também serviu de modelo para outros autores, como François Fénelon [ou François de Salignac de La Mothe-Fénelon (1651-1715)].

30 “[...] une tragédie renferme une infinité de tableaux. Le peintre qui fait un tableau du sacrifice d'Iphigenie, ne nous represente sur la toile qu'un instant de l'action." 
Fénelon (1740) parece haver influenciado Diderot de modo muito significativo, quando tratou a eloquência na poesia e criticou a excessiva ornamentação a ela aplicada, compreendo que isso afastava a obra poética da linguagem encontrada na fala cotidiana. Fénelon, na compreensão de Worvill, buscava uma poesia que se rebelasse contra ornamentos que acentuavam o virtuosismo do poeta ou daquele que fala; ou seja, a verdadeira retórica torna invisível o orador e comunica a verdade: "O poeta desaparece; não se vê mais do que aquilo que ele nos faz ver, não se ouve mais do que ele fala. Esse é o poder da imitação e da pintura". ${ }^{11}$ (FÉNELON, 1740, p. 96, tradução nossa) Ele considerava a possibilidade de um "pintar com palavras", que a elas daria a equivalência da ilusão artística alcançada pela pintura, quebrando os limites da descrição, para fazer ver o objeto descrito.

Vale lembrar que a obra de Fénelon interage com uma importante discussão acerca da pintura na França. Enquanto uns defendiam aspectos técnicos, como o uso da cor, a técnica empregada pelo artista (como os chamados coloristas), outros se interessavam pelos temas tratados. Tal debate punha em evidência a intenção de conceder à pintura o status de arte liberal, em contraposição a uma limitada posição de "ofício". Incluindo nas suas obras temas de reconhecida significação histórica, para evidenciar nos seus quadros o alcance dos assuntos abordados, o pintor demonstraria sua posição de artista, de pensador. Fénelon, contudo, não parece tomar partido, o que sugere seu interesse tanto pela qualidade técnica figurativa, que era defendida pelos coloristas ligados a Peter-Paul Rubens (15771640), quanto pelo contexto representado na obra, cujo exemplo está relacionado a Nicolas Poussin (1594-1665).

Pode-se presumir que obras como a de Fénelon tenham deixado marcas importantes em Diderot, atuando em conjunto com sua observação do teatro e com seu desejo de vislumbrar na cena uma discussão da vida que pusesse em foco a sociedade francesa em transformação. Tudo isso gerou um impulso na direção da sua teoria para o espetáculo. Se o coup de théâtre lhe parecia uma estratégia grosseira e simplória, como uma pincelada que ao se tornar evidente descaracterizaria o trabalho do pintor, o caminho estava aberto para pôr do mesmo lado a enargeia da palavra e aquela da imagem. A incorporação dos tableaux à cena dispensaria a falsidade e aniquilaria a deficiência do coup de théâtre que afastava o espetáculo do público, destituindo-o da sua capacidade de incorporar os signos naturalmente representados. O espetáculo contaria com uma contribuição exemplarmente visual, construindo quadros, no palco. A elaboração desses quadros

31 "Le Poète disparoît; on ne voit plus que ce qu'il fait voir, on n'entend plus que ceux qu'il fait parler. Voilà la force de l'imitation \& de la peinture." 
emprestaria qualidades pictóricas à práxis cênica, propondo nova compreensão da ilusão teatral e, também, novas estratégias dramatúrgicas. Worvil classifica tal decisão como uma aplicação literal da ut pictura poesis.

É possível que a aplicação das proposições de Diderot na cena propriamente dita pode ter sido limitada por duas condições presentes no teatro francês do século XVIII: a primeira delas refere-se à sua organização espacial, que permitia a presença de público em regiões laterais do palco, incluindo os espectadores nos tableaux criados na cena. ${ }^{32}$ (Figura 88) E, ainda, as condições técnicas da luz artificial aplicada em cena naquele tempo, que, aos olhos da luz teatral atual, limitariam os resultados. Pode-se conjecturar que o público seria convocado a atender a uma espécie de acordo tácito, apreendendo o esforço do artista para criar na cena imagens que repercutissem a exigência visual da dramaturgia. É possível, portanto, compreender o desejo de Diderot de aproximar o espetáculo do espectador, incluindo temas e linguagem que por si só revelassem feições da própria vida de quem ia ao teatro.

\section{O PALCO COMO PINTURA EXEMPLAR}

Desde o autor até qualquer outro artista ou teórico que reflete sobre a natureza do espetáculo, todos estão ligados a elaborações da visualidade, ainda que intuitivamente ou mesmo, inadvertidamente. Por essa razão, os teóricos, assim como os artistas, têm como opção dedicar algum cuidado às relações entre a luz e o acontecimento cênico. Reconhecer efetivamente a importância de tais relações pode ser um caminho para evitar tratamentos exclusivamente mecânicos, superficiais ou, como já foi dito, cosméticos. Diderot parecia discordar de um dramaturgo que, acreditando na hegemonia da palavra, desconsiderasse a visualidade. Aqui se incorpora uma abordagem transversal da cena que indica conexões entre a dramaturgia e o acontecimento cênico, validadas por interações visuais que questionam o tratamento do espetáculo como um punhado de camadas superpostas das quais a luz é a derradeira.

Na opinião de alguns comentadores, o período em discussão denota uma incipiente relação do teatro francês com as questões visuais. Destaque-se a resistência francesa em assimilar diferenças de tratamento entre plateia e palco já praticadas na Itália, onde se retirava a luz da plateia para tornar o palco mais visível, estabe-

32 Essa prática, que só seria afastada no último quarto do século XVIII, era muito criticada, não somente por Diderot, mas também por outros estudiosos, como Voltaire. 
lecendo o contraste que dava a ilusão de maior brilho. A resistência francesa teve grande importância para o trabalho de Jean-Nicolas Servan [ou Giovanni Niccolò Servando e, ainda, Servandoni (1695-1766)]; nascido na cidade de Florença, ele estudou em Roma e trabalhou como cenógrafo em Portugal, para depois encaminhar sua carreira na França. Com Servandoni, o teatro francês recebeu a incorporação da radicalização italiana, escurecendo a plateia para acentuar o palco.

As pinturas deixadas por Servandoni demonstram seu grande interesse por uma imagem cenográfica com alto grau de excelência na ilusão de tridimensionalidade, como no capriccio ${ }^{33}$ romano pintado por volta de 1731 (Figura 89). Mesmo que poucos cenários propriamente ditos, de sua autoria, sejam hoje conhecidos, sabe-se que a primeira metade do século XVIII na França foi surpreendida pelos empreendimentos espetaculares de Servandoni. Gösta Mauritz Bergman (1977) cita os relatos detalhados que aparecem no Mercure de France sobre seus espetáculos, dando conta da exuberância que resultava da aplicação da luz. Servandoni teria aplicado com maestria a transparência, o brilho e a capacidade reflexiva de diversos materiais, para criar resultados que causavam exclamações e muitos elogios, inclusive do próprio Diderot: "Este Servandoni é um homem que todo o ouro do Peru não enriquecerá. [...] Grande cenotécnico, grande arquiteto, bom pintor, sublime cenógrafo, não há nenhum desses talentos que ele não detenha".34 (DIDEROT, 1796, p. 186, tradução nossa)

Servandoni, no entanto, teria ido mais longe ao elaborar espetáculos nos quais nenhuma ação humana ocorria efetivamente e o ser humano aparecia com uma função diferenciada: pintadas no dispositivo cenográfico, as "personagens" funcionavam como referência para a apreensão da proporção (espacial) proposta pelas imagens. A proposição era colocar o espectador diante de uma experiência visual, dispensando o apelo a quaisquer outros sentidos. Estava abolida a música, o ator e, com ele, a palavra.

O primeiro espetáculo da série, cujo tema era a Basílica de São Pedro, em Roma, mostrava o interior da igreja exatamente como se veria no local propriamente dito,

33 Este termo se refere a imagens criadas pelos pintores, comumente inseridas na categoria paisagem, nas quais se observava um grau de fantasia já que não se referiam a um lugar idenficável na experiência cotidiana. Inicialmente, no século XVII, os capriccios incluíam elementos arquitetônicos e o pintor Marco Ricci (1676-1730) é mencionado como o responsável pelo aprimoramento desse tipo de pintura, no qual os seres humanos e animais retratados não representam o objeto principal da imagem [como em Poussin e Claude Lorain (1630-1682)], sendo que a livre elaboração arquitetônica e/ou a paisagem representam o tema central. Depois de Ricci, Giovanni Paolo Paninni (1691-1765) produziu uma série de obras célebres nesse caminho, seguido de outros como Canaletto [Giovanni Antonio Canal (1697-1768)] e Piranesi [Giovanni Battista Piranesi (1720-1778)].

34 “Ce Servadoni est un homme que tout l'or du Perou n'enrichiroit pas. [...] Grand machiniste, grand architecte, bon peintre, sublime decorateur, il n'y a aucun de ces talents qui ne lui ait valu des sommes." 
e desconsiderava até mesmo a narrativa linear da representação teatral da época. (PELLETIER, 2006, p. 280) Era uma busca pela emoção que poderia ser provocada através da apresentação sucessiva de espaços tratados de modo próprio, pela luz. Na compreensão do artista, a visão se bastava como sentido último na relação com o público, resultando naqueles, assim denominados, espetáculos ou jogos de óptica (spéctacles ou jeu d'optique). Traduzir essas expressões como "teatro óptico" sugeriria certa estranheza na tautologia, uma vez que, como já foi reiterado aqui, não se pode compreender amplamente o termo teatro, sem considerar suas implicações visuais, desde o teatro grego da Antiguidade.

Dentre os espetáculos, Quatremère de Quincy ${ }^{35}$ destacou a peça Pandora (Pandore), que descreve com entusiasmo:

A abertura da peça representava o caos e sua elucidação de acordo com as ideias dos poetas. A imagem da natureza, tal qual descrita na idade do ouro, sucedia à confusão, e essas diversas mudanças serviam como prólogo para a história de Pandora. Sua ascensão ao céu, levada por Mercúrio, sua estadia no Olimpo, onde recebeu os presentes dos deuses, a doação da famosa caixa e seu retorno para a terra, formam um conjunto de cenas surpreendentes e brilhantes. Não havia nenhuma figura viva na ação. [...] Essa grande representação, que durou mais que uma hora, terminava com a abertura da caixa fatal e com a imagem dos males que ela espalhou sobre a terra. ${ }^{36}$ (QUINCY, 1830, p. 289, tradução nossa)

Servandoni usava personagens pintadas em imagens sucessivas, sugerindo um movimento continuado. Esses espetáculos, segundo Quincy, lhe valeram a reputação de pintor e poeta, cuja poesia se inscrevia exclusivamente em estímulos visuais. Pode-se avaliar a reação a tal tendência, na declaração de Quincy, escrita no início do século XIX:

Considerando o emprego que deles se faz no teatro, os cenários geralmente não representam mais que um acessório do espetáculo, um meio de mostrar para o olhar os lugares da ação dramática,

35 Antoine-Chrysostome Quatremère de Quincy, (1755-1849) arqueólogo, filósofo, crítico de arte e político francês 36 “L'ouverture de la pièce représentait le chaos et son débrouillement selon les idées des poètes. L'image de la nature, telle qu'ils la décrivent sous l'âge d'or, succédait à la confusion, et ces différents changements servaient de prologue à l'histoire de Pandore. Son enlèvement au ciel par Mercure, son séjour dans l'Olympe, où elle recevait les présents des dieux; le don de la fameuse boîte et son retour sur la terre, formaient une suite de scènes aussi nouvelles qui brillantes. Aucune figure vivante ne se mêlait à l'action. [...] Cette grande représentation, qui durait plus d'une heure, se terminait par l'ouverture de la boîte fatale et par l'image des maux qu'elle répandit sur la terre." 
os países onde se espera que ela aconteça. Coube a Servandoni dar àquilo [ao cenário] que não é mais que um acompanhamento do drama, a integridade de uma espécie de drama sem palavra, e de criar no espírito o interesse por uma ação cênica dirigida exclusivamente aos olhos. ${ }^{37}$ (QUINCY, 1830, p. 288, tradução nossa)

Sabe-se que na continuação desse ousado projeto espetacular ele adicionaria música e, eventualmente, atores. As mudanças, contudo, não devem ser compreendidas como enfraquecimento da visualidade no seu espetáculo, como será destacado a seguir. Para o propósito do trabalho em curso, aliás, basta o registro da tendência inicial de um artista que sonhava com a espetacularidade de uma cena fundamentada na ação da luz, promovendo hegemonia do discurso visual. Por outro lado, como já foi dito, uma hegemonia de tal natureza seria transitória no empreendimento teatral, como se pode observar no trabalho do próprio Servandoni. Seu retorno ao espetáculo, que se constituía da interação entre espaço, tempo e ação - presença humana, portanto -, reafirma a contribuição vigorosa da visualidade.

Tal exclusividade da visão é, quando menos uma utopia, considerando que o espectador não teria capacidade de anular outros sentidos, a menos que se aplique algum tipo de artefato ou tecnologia ainda desconhecida. Mesmo permanecendo sentado na sua poltrona durante todo um espetáculo, ele experimenta imagens mentais que o sensibilizam integralmente, provocando visões, aromas, texturas, temperaturas, sons, e assim por diante. Parece razoável reconhecer que o fascínio de Servandoni por imagens materialmente criadas no palco não lhe concedia o acesso exclusivo à visão do espectador, cujo imaginário interage com a cena e provoca as mais diversas sensações, impedindo uma abordagem simplória e/ ou exclusivista da experiência visual. Entretanto, essa espécie de "drama visual", assim como a especulação acerca de uma ação cênica dirigida "exclusivamente" aos olhos, revela a força e o apelo da visão.

Servandoni chegou à França em 1724 e, quatro anos depois, se tornou PintorCenógrafo da Academia Real de Música (Académie Royale de Musique), isto é, a Opéra de Paris, mantendo-se na posição por quase duas décadas, e trabalhando em mais de sessenta projetos cenográficos. Em 1737, ele obteve os direitos para uso

\footnotetext{
37 “Les décorations scéniques, considérées dans l'emploi qu'on en fait au théâtre, ne son ordinairement qu'un accessoire du spectacle, un moyen de mettre, pour les yeux, l'effet de l'action dramatique d'accord avec les lieux, les pays où elle est censée se passer. Il appartint à Servadoni de pouvoir donner a ce qui n'est l'accompagnement du drame, la valeur entière d'une sorte de drame sens parole, et d'intéresser l'esprit à une action scénique par le seul secours des yeux."
} 
da casa de espetáculos Sala das Máquinas (Salle des Machines), nas Tuilleries, em Paris, cuja denominação decorria das elaboradas possibilidades mecânicas instaladas pelo arquiteto Gaspari Vigarani (1586-1663), que o construiu para o rei Louis XIV, adaptando uma edificação já existente, sob a demanda de Mazarin..$^{38}$ As características arquitetônicas da Salle des Machines, de profundidade muito superior à sua reduzida dimensão horizontal, abrigaram o teatro ótico inicialmente criado por Servandoni.

Sua estratégia era a aplicação do discurso visual no diálogo com o público. Para tanto, a scena per angolo trazia grande contribuição: a combinação dos múltiplos pontos de fuga, dispostos fora do alcance visual do espectador, com enormes elementos cenográficos implantados no primeiro plano da caixa-cênica, produzia um espaço cênico cujos limites se projetavam, virtualmente, para "fora do palco". Cenários que contavam com pilares de grandes dimensões dispostos logo depois do proscênio, e se estendendo para cima, atrás da bambolina régia (ou mestra), sugeriam uma dimensão vertical inesperada, no interior de um palco.

Durante os dezoito anos nos quais esteve à frente da Salle des Machines, maravilhando o público com inúmeros espetáculos, Servandoni aplicou temas históricos e mitológicos. Quincy comentou seu espetáculo, cujo tema era uma jornada ao inferno, chamando a atenção para o tratamento visual que resultou em grande apelo para o público: "Ele favorecia, no mais alto nível, passagens súbitas das sombras à luz, do terrível ao gracioso". ${ }^{9}$ (QUINCY, 1830, p. 290, tradução nossa) Pode-se registrar tanto a repercussão no espectador, quanto o empenho e a capacidade do artista de alcançar tal resultado, reiterando a contribuição da luz, mesmo levando-se em conta as condições técnicas das quais ele dispunha. Num momento em que o teatro francês incorporava a presença de público no palco propriamente dito, propor a interação entre o dispositivo cenográfico e a luz, como o principal meio de contar as histórias e provocar sensações e emoções, era um ato de ousadia.

O surpreendente empreendimento teatral ganharia abrangência, a ponto de influenciar o arquiteto Le Camus de Mézières (1721-1789), repercutindo na sua teoria da arquitetura. Já na maturidade, em 1780, ele escreveu O gênio da arquitetura (Le genie d'architecture), onde evocou a cenografia e o teatro como fonte de inspiração e orientação:

38 Jules Mazarin, ou Giulio Raimondo Mazzarino (1602-1661). Cardeal, diplomata e político, sucedeu Richelieu.

39 "Il favorisait au plus haut point les passages subits des ténèbres à la lumière, du terrible au gracieux." 
Respeitemos [ou asseguremos] a magia da óptica; assim o artista deve desenvolver seus talentos e dar a conhecer a envergadura do seu trabalho. [...] Ele pode aquecer suas ideias estudando pinturas e gravuras, como aquelas que se veem nos cenários dos nossos teatros. ${ }^{40}$ (MÉZIÈRES, 1780 , p. 142, tradução nossa)

Se por muito tempo, desde a Renascença, seria difícil encontrar um cenógrafo que não fosse também arquiteto ou pintor - mesmo tendo Servandoni recebido formação em arquitetura -, vemos em Mézières o trabalho do cenógrafo repercutindo na obra do arquiteto. Na segunda metade do século XVIII, outros arquitetos como Claude-Nicolas Ledoux (1736-1806) e Étienne-Louis Boullée [(1728-1799), também conhecido como Arquiteto das Luzes], discutem a arquitetura como linguagem, criticando a obediência aos cânones clássicos, cujo modelo estava na aplicação das ordens arquitetônicas: jônica, dórica, coríntia e até a versão romana compósita. Na compreensão dos estudiosos, a arquitetura poderia criar um discurso silencioso através de imagens capazes de provocar os sentidos, levando a sensações análogas ao uso para o qual a edificação foi concebida, e até alcançar o status de "poema silencioso".

A parceria indicada por Le Camus de Mézières, entre o espaço cênico e a arquitetura, na busca de estados emocionais, deixou um legado do tratamento atmosférico aplicado à cena. Observando com atenção, pode-se notar como tal tratamento está intimamente ligado à luz. A identificação de atmosferas é notável e pode atuar, até hoje, como aprendizado para jovens artistas que se aventurem no teatro, em particular, diretores e designers.

No comentário a seguir, ele trata de um espetáculo denominado Representação com máquinas (Représentation en machines), que teve lugar no Théâtre des Tuilleries (ou Salle des machines) Paris, em 1741:

Quem pode resistir, então, a essa tripla magia [juntas, a pintura, a arquitetura e a escultura] que faz a alma experimentar quase todos os afetos e sentimentos conhecidos por nós? [...] Queremos julgar com certeza e satisfação? Voltemos nossos olhos para os cenários dos nossos palcos, onde a simples imitação das obras engendradas pela arquitetura determina nossas condições [emocionais]. Aqui está o palácio encantado de Armida, tudo é belo e voluptuoso, pensamos que foi erguido pelas instâncias do amor. Uma nova tela aparece; é a morada de Plutão, que leva

40 "Ménageons toute la magie de l'optique; c'est dans ce cas où l'Artiste doit développer ses talents, \& faire connaître l'étendue de son Art. [...] Il peut échauffer ses idées par l'étude des tableaux \& des estampes, par celles de nos décorations de théâtre." 
o horror e o terror às almas. Vemos o Templo do Sol? Ele produz admiração. A aparência de uma prisão dá lugar à tristeza; edifícios destinados a uma festa, rodeados por jardins, fontes e flores, preparam para a alegria e o prazer. Ao ver a floresta de Dodone, a alma se modifica; torna-se impressionada pelo horror sagrado da árvore. | O famoso Servandoni, cuja genialidade e conhecimento dos segredos da sua arte, nos surpreendeu e encantou na cena, [...] em um espetáculo silencioso, nos fez sentir o efeito do calor escaldante do Sol. Vimos o acampamento de Godefroy sob o fogo de Canícula, quase sem sombra, céu vermelho, uma terra seca, um efeito de luz que invoca um ar em chamas; tudo produz uma ilusão da qual nenhum expectador pode se afastar, todos pensavam sofrer; fomos submetidos ao poder da arte, ele nos fez, sem dúvida e com sucesso, sentir na alma a ideia de um frio intenso, como se nos tivesse apresentado a imagem do clima, onde algumas bétulas nuas são as únicas plantas que se erguem das rochas cobertas de neve eterna; um ar sombrio, um céu pálido e uniforme anunciava geadas prontas para se precipitar. Rios congelados e imóveis, [...] ele não apresentava mais que uma natureza privada da vida e de movimento. Esse espetáculo nos fez arrepiar. Como nos sentimos diante do contraste entre as trevas mais espessas e o dia mais puro, entre os encantos da calmaria e os distúrbios da tempestade e dos ventos? As nuanças, as gradações, nos afetam. | Portanto, as disposições da forma, seu caráter, juntos, eles se tornam a fonte inesgotável das ilusões. É desse princípio que devemos partir, quando desejamos produzir estados afetivos através da arquitetura, quando queremos falar ao espírito, tocar a alma, e não apenas nos contentarmos, através da construção, em colocar pedras sobre pedras, e imitar arranjos aleatórios e ornamentos acordados ou tomados como empréstimo, sem profunda avaliação. ${ }^{41}$ (MÉZIÈRES, 1780, p. 4-7, tradução nossa)

\footnotetext{
41 “Quelles sont les causes de ces différents effets? Démelons -les, s'il est possible, l'existence n'en est pas douteuse; combien se montrera-t-elle plus sensible, si l'on réunit à l'Architecture, la Peinture \& la Sculpture? (p. 5) Qui peut résister alors à cette triple magie dont les prestiges sont éprouver à l'âme presque toutes les affections et sensations qui nous sont connues? Voulons-nous en juger avec certitude \& satisfaction? Jettons les yeux sur les décorations de nos Théâtres, où la simple imitation des ouvrages enfantés par l'Architecture détermine nos affections. Ici, c'est le Palais enchanté d'Armide; tout y est à la foi magnifique \& voluptueux; on devine qu'il futélevé par les ordres de l'Amour. La toile change; c'est le séjour de Pluton qui porte l'horreur \& l'effroi dans les âmes. Voyonsnous le Temple du Soleil? II produit l'admiration. L'aspect d'une Prison fait naître la tristesse; des Appartements déstinés à une fête, entourés de jardins, de fontaines \& de fleurs, excitent la gaieté \& préparent aux plaisirs. A la vue de la forêt de Dodone, l'ame est émue; on est saisi de l'horreur sacrée des bois. | Le fameux Servandoni y dont le génie sécond \& la connoissance des secrets de son Art nous ont surpris \& charmes sur la scêne, a sçu, dans un
} 
Sua apreensão das mais diferentes atmosferas que progressivamente se instalavam no espetáculo, é exemplar. Não se tratava simplesmente de mostrar um ou mais lugares, e sim, da intensa busca pelo estabelecimento de contrastes que determinavam variações na melodia visual silenciosa, no tom, no tema; o carvalho sagrado (ou o fagus sylvatica, ou ainda faia) na floresta do santuário de Dodone fazia emudecer a alma. Observando uma imagem dessa imensa árvore (Figura 90), pode-se construir uma opinião acerca da visão testemunhada pelos soldados da Cruzada cristã, comandada pelo cavaleiro franco Godefroy de Bouillon (ca. 10601100), na campanha que resultou na tomada de Jerusalém, em combate contra os sarracenos. Voluptuosidade, terror, alegria, prazer, integram as robustas imagens invocadas por Le Camus, incluindo o calor relacionado à Canicule, termo que se refere às altas temperaturas causadas por condições climáticas particulares, cuja origem é a palavra italiana canicula (pequena cadela), que se refere aos "dias de cão", ou ao excesso de calor no verão europeu, sendo também o outro nome da estrela Sirius.

Profundamente tocado pelo espetáculo, o arquiteto revela a contribuição decisiva da luz para a criação de cada uma das imagens comentadas. Amplia-se, então, a apreensão da cena, quando ela provoca imagens mentais originadas na visibilidade, mas prenhes de aromas, cores, formas, texturas e ruídos, que qualificam cenicamente o ambiente, criando uma visualidade particular.

Qualquer que seja a época, o estilo, a escola, esteja o artista ligado ao denominado ilusionismo, ou busque sua desconstrução, a práxis cênica demonstra o interesse por atmosferas a cada momento da sua história. Importa, no trabalho de Le Camus, o destaque para a função da cena de compartilhar com o espectador as mais diversificadas atmosferas, e para a contribuição da luz para a realização de tal

\footnotetext{
Spectacle muet y faire éprouver l'effet de l'ardeur brûlante du Soleil. On y voyoit le Camp de Godefroy en proie aux feux de la Canicule; presqu'aucune ombre, un ciel rougeâtre, une terre aride, un effet de lumière qui rappelloit celui d'un air enflammé; tout y produisoit une illusion dont aucun Spectateur n'étoit à l'abri; on croyoit souffrir, on étoit soumis à la puissance de l'Art, ïl eût sans doute, avec autant de succès fait passer dans nos âmes l'idée d'un froid cuisant, s'il nous eût présenté l'image de ces climats où quelques bouleaux dépouillés sont les seuls végétaux qui s'élèvent sur des rochers couverts de neiges éternelles; un air sombre, un ciel pâle \& uniforme auroit annoncé de nouveaux frimats prêts à se répandre. Des fleuves glacés \& immobiles, des sources surprises \& comme arrêtées dans leur suite n'auroient présenté (p. 7) qu'une nature privée de vie \& de mouvement. Ce spectacle nous eût fait frissonner. Que n'éprouvons-nous pas dans les oppositions des ténèbres les plus épaisses, \& du jour le plus pur, dans les agréments du calme \& les désordres de la tempête \& des vents? Les nuances, les gradations nous affectent. | Ce sont donc les dispositions des formes, leur caractère, leur ensemble qui deviennent le sond inépuisable des illusions. C'est de ce principe qu'il faut partir, lorsqu'on prétend dans l'Architecture produire des affections, lorsqu'on veut parler à l'esprit, émouvoir l'âme, \& ne pas se contenter, en bâtissant, de placer pierres fur pierres, \& d'imiter au hasard des dispositions, des ornements convenus ou empruntés sans méditation. L'intention motivée dans l'ensemble, les proportions \& l'accord des différentes parties produisent les effets \& les sensations."
} 
desejo. Sabemos que sua proposição recebeu críticas que consideraram exagero aplicar tais pressupostos em projetos dos edifícios. Seu testemunho, por outro lado, atestava o valor das atmosferas para a criação da práxis cênica.

A relevância da obra de Servandoni, para a presente abordagem, reafirma-se no artigo de Jérôme de la Gorce, no qual ele comenta um documento encontrado no Museu de artes decorativas (Musée des arts decoratifs), em Lyon. Trata-se de uma perspectiva relacionada ao dispositivo cenográfico para o espetáculo O triunfo da harmonia (Le triomphe de l'harmonie), classificado como Balé Heroico (Ballet heroique), pelo autor do libreto, Jean-Jacques Lefranc Pompignan (1709-1784), e cuja estreia se deu em 9 de maio de 1737, com música de FrançoisLupien Grenet (ca. 1700-1753) (Figura 91). ${ }^{42}$ Ainda que a citada ópera não tenha hoje grande repercussão, a inscrição que aparece na parte inferior da mesma folha de papel onde se vê a perspectiva, contribui para definir sua importância: "Aparência da cenografia da cidade de Tebas, criada e pintada pelo Sr. Servandoni para o $3^{0}$ ato do Le triomphe de l'harmonie". ${ }^{43}$ (DE LA GORCE, 2009, p. 578, grifo e tradução nossos)

O trabalho de Servadoni como cenógrafo tem sido estudado a partir da observação de plantas, cortes, descrições e relatos encontrados na publicação da época Mercure de France, dada a escassez de imagens originais da época. O citado desenho em perspectiva ganha importância precisamente porque sugere tridimensionalidade, revelando parte substancial do projeto, do tratamento desejado pelo cenógrafo. Le triomphe de l'harmonie é o último espetáculo para o qual Servandoni contribuiu, na sua passagem pela Opéra, já comentada, antes de assumir a Salle des machines.

No libreto de Pompignan (1737), a divisão hoje classificada em atos é identificada como entrées, sendo o texto composto de um prólogo e três entrées. Cada uma dessas partes apresenta ação dramática independente, dispensando ligação entre elas. A primeira cena do Prólogo revela a Paz, descendo do céu, ao som de tímbales e trompetes, enquanto o Coro exclama: "A Paz vem realizar nossos desejos, | Que felicidade! Que glória! Ela traz [de novo] os prazeres | sobre as asas da vitória".44 (POMPIGNAN, 1737, p. 4, tradução nossa) Podem-se observar pistas para a atmos-

\footnotetext{
42 Este foi provavelmente o último projeto de Servandoni no Palays Royal, antes da sua empreitada na Salle des Machines, com o teatro óptico.

43 "Aspect de la décoration de la Ville de Thèbes, inventé e peint par le Sieur Servandoni pour le ze acte du Triomphe de L'Harmonie."

44 "La Paix vient combler nos désirs, | Quel bonheur pour nous! Quelle gloire! | Elle rameine les plaisir | sur les aîles de la Victoire."
} 
fera na qual o autor abriria o espetáculo, fosse ele o diretor. Com a identificação da perspectiva já citada, o terceiro ato ganha maior importância para a presente abordagem: no texto manuscrito, abaixo da ilustração, pode-se ler: "A parte do papel que se eleva, mostra um segundo cenário que sai do porão, quando Amphion ergue novas muralhas para a cidade, com o poder da sua voz". ${ }^{45}$ (SERVANDONI apud DE LA GORCE, 2009, p. 583, tradução nossa)

O terceiro ato tem como tema o mito de Amphion, um dos filhos de Zeus e Antíope, e considerado criador da música, juntamente com seu irmão Zethos; ele seria também o fundador de Tebas, diante da qual se passa a ação. Cabe destacar o ambiente descrito pelo autor:

O palco mostra florestas, cavernas e rochedos; um acampamento de selvagens instalado diante da cidade de Tebas, que aparece ao fundo semidestruída. A Cena se passa no fim da noite. ${ }^{46}$ (POMPIGNAN, 1737, p. 35, tradução nossa e grifo do autor)

Um dos aspectos abordados por De La Gorce (2009) é a comparação entre a perspectiva localizada em Lyon e uma planta-baixa já conhecida e mantida pelo National museum, em Estocolmo (Figura 92). O que pode sugerir desencontro entre os dois, talvez possa apontar possibilidades para algum esclarecimento: observa-se na planta-baixa uma série de elementos (tapadeiras ou trainéis), que não parecem estar presentes na perspectiva de Servandoni. Sem acesso ao texto manuscrito, incluído no desenho técnico mantido pelo Museu Nacional da Suécia, é possível presumir que alguma modificação possa ter ocorrido, levando cada um deles a incluir informação diferenciada, de acordo com as datas de execução e/ou proposição do desenho em si. Por outro lado, vale considerar que a perspectiva esteja intencionalmente incompleta, no que se refere ao ambiente da cena, uma vez que Servandoni tenha particularmente nela representado a "cidade de Tebas, que aparece ao fundo semidestruída", incluindo as muralhas, à esquerda-alta, para indicar o tratamento planejado para o momento específico da mencionada intervenção de Amphion.

O que parece ausente, ao menos, é uma representação dos rochedos, das cavernas, das florestas, e daquilo que ele chama "campo de selvagens". A rubrica, no entanto, traz ainda em destaque a indicação da atmosfera que o dramaturgo considera imprescindível à ação, para a intriga que ele propõe: "a cena se passa no fim

45 "La Partie Du Papier que se réleve [souléve] forme une seconde Décoration, qui sort de dessous le théâtre, lorsqu'Amphion élève de nouveaux murs à la ville, par le charme de sa voix."

46 "Le Théâtre représente des Forêts, des Cavernes, des Rochers; | un Camp de Sauvages y est formé devant la Ville de Thebes, qui paroit dans le fond à demie ruiné. | La Scène se passe sur la fin de la nuit." 
da noite". Originalmente destacada em itálico, essa observação soa quase como um alerta, como se ele estivesse dizendo: "Essa é a luz, a atmosfera que tenho em mente, ao conceber a cena!" E isso se amplia no solo de Niobe, filha do Rei Tantale e esposa de Amphion: "Amor do Universo, chama brilhante e pura, Aurora, que teus fogos abrandem meu temor! Os horrores da noite desvanecem diante de ti; Teus raios [benevolentes] confortam a natureza [...]". 47 (POMPIGNAN, 1737, p. 35, tradução nossa e grifo do autor).

Note-se que logo depois da rubrica de abertura que anuncia o "fim da noite", Niobe anuncia as cores, o tom, o brilho, a pureza e o conforto que acompanham o dia especial. Isso, o desenho de Servandoni não revela e, mesmo que ele tivesse deixado uma pintura, com sua impressão da atmosfera, sua efetivação na cena estaria ligada à conjuntura técnica (incluindo instrumentos e acessórios disponíveis àquele tempo), além de procedimentos decorrentes dessa mesma conjuntura.

\section{Tênues fronteiras entre ilusão e realidade}

Mesmo meio século depois da iniciativa de Servandoni ainda podem ser encontradas críticas à falta de controle da luz nos teatros franceses, como em Boullée (apud Rosenau, 1976, p. 96, grifo e tradução nossos):

Há outro aspecto que tem recebido ainda menor atenção: um grande volume de observações sobre isto me torna capaz de lidar com o problema. Refiro-me aos métodos de iluminar uma plateia, de acordo com o modo como a peça deve tocar o espectador. Se o título de uma peça induziu pensamentos sombrios, ninguém que esteja acomodado em uma plateia muito iluminada, deixa de ter dificuldade para afastar-se das sensações induzidas pelo brilho dessa luz, quando a cortina for levantada, revelando uma cena sombria. O esforço ao qual se é obrigado, para colocar-se na atmosfera apropriada, destrói a ilusão; a [totalidade do] efeito destrutivo na performance é desconhecido. ${ }^{48}$

\footnotetext{
47 "Amour de l'Univers, flamme brillante et pure, | Aurore, que tes feux redoublent mon effroi! | Les horreurs de la nuit s'effacent [effacent] devant toi; | Tes rayons bienfaisons consolent la nature, | [...]."

48 "There is another aspect that has received even less attention; a mass of observations about it have enabled me to deal with it. It concerns methods of lighting an auditorium according to the effect the work should have presented on the audience. If the title of a play has induced gloomy thoughts, no one seated in a brightly lit auditorium, will not experience some difficulty in tearing himself away from the sensations induced by the brightness of the lighting when the curtains rises and suddenly reveals a sombre scene. The effort he is obliged to make to put himself in the right mood destroys the illusion; the destructive effect on the performance is unknown."
} 
Demonstrando amplo espectro de preocupações com a atividade - incluindo a segurança, a excelência na operação técnica e no trabalho do responsável pelo espetáculo - referendadas pela larga experiência como observador, por ele mesmo atestada, Boullée não apresentava queixas referentes aos espetáculos, do ponto de vista daquilo que se contemplava nos palcos. Em sua opinião, os responsáveis pela cena alcançariam importantes resultados caso fosse corrigida a presença indevida de luz na plateia, durante a performance. O que vale dizer: quando um autor propunha determinada atmosfera, como faz Pompignan através de Niobe, ele sabia o que esperar. O dramaturgo atento era capaz de imaginar as diferenças entre a atmosfera presente na sua dramaturgia e o resultado provável, no momento de um espetáculo.

A organização dos sistemas de iluminação de teatros na França do século XVIII apresentava, com certa variação, um padrão que se constituía na aplicação de velas de sebo, ou de cera animal em candelabros sobre o proscênio, lamparinas na ribalta, assim como sistemas de velas no interior da caixa cênica. Essa organização sugeria um tratamento previsível, simétrico e, provavelmente, repetitivo. Progressivamente, a introdução de ribaltas móveis associada à redução de candelabros na plateia, e a implantação de luminárias Argand, tratadas adiante, estabeleceu uma acentuação visual da ação no palco. A incorporação de superfícies refletoras (réverbères), já implantadas na iluminação pública, teria incrementado a luz projetada sobre o centro da caixa cênica, e também nos telões de fundo.

Mesmo considerando um provável padrão no tratamento da luz para a cena nesse período, que proporcionava a regularidade já mencionada, há registros da preocupação com certas diferenças entre os espetáculos, como Gösta M. Bergman (1977) especula. Em 1757, Atália [Athalie, (abril)] e Ifigênia em Taurida [Iphigénie en Tauride (junho)], ambas de Racine, parecem ter merecido especial atenção, como observa Bergman (1977), citando o inventário de instrumentos usados na iluminação. Mesmo caso de Órfãos da China (Orphelin de la Chine), de Voltaire, levada ao público na temporada 1759-176o, com cenários de Paolo Antonio Brunetti (1726-1783), pintor e cenógrafo muito ativo no período, tendo elaborado também cenários para Semiramis, também de Voltaire, escrita em 1749. Aliado à comentada possibilidade de ampliação dos instrumentos de iluminação, o interesse pelo tratamento diferenciado de certas peças começa a indicar um novo princípio acerca da aplicação da luz na cena a partir da segunda metade do século XVIII.

Certas mudanças ocorridas nesse momento indicavam rotas para o robustecimento da modernidade na práxis cênica. A reforma realizada em 1759 no teatro Comédie Française, em Paris, delineia as principais tendências dessas rotas. 
Bergman sublinha traços do ilusionismo romântico que ingressaria na arte do século XIX e arregimentaria esforços de artistas envolvidos nos espetáculos. Na trilha desse tom romântico, o teatro francês anunciava a necessidade de diferenças no tratamento da luz empregada na cena. No dizer de Bergman, em novas imagens que se insinuavam lentamente como que apontando para uma nova função da luz.

A ilusão indispensável para a abordagem romântica, na qual lugar e atmosfera eram imprescindíveis, começou a tomar corpo nos espetáculos da Comédie Française quando, na mencionada reforma, foram retirados os bancos nos quais espectadores eram acomodados nas laterais do palco. No entendimento dos responsáveis pela reforma esses espectadores produziam graves limitações aos espetáculos. Além de impedirem flexibilidade no trânsito das personagens e destruírem a ilusão, eles ocupavam um espaço que poderia ser usado pelas personagens e pelo dispositivo cenográfico propriamente dito. Por outro lado, quando são consideradas as diversas tendências não ilusionistas difundidas desde o início do século XX, ao colocar espectadores no palco essa organização do espaço cênico era muito revolucionária: o público estava dentro da cena, tomava parte dela.

Depois da reforma, o palco livre foi parcialmente retomado pela ação. Apesar disso, o espaço da cena era agora domínio apenas relativo da personagem, pois o espectador era ainda acomodado em camarotes ao lado do palco (Figura 93). Os figurinos ainda pareciam sujeitos à estilização exagerada, se não forem observados com a atenção que permite identificar tentativas de aproximação histórica com a ação e com as personagens envolvidas em cada trama. A qualidade romântica ainda necessitava da contribuição da luz para incorporar atmosfera ao ambiente da ação. Os sistemas de tapadeiras ou traineis laterais permitiam, ou sugeriam, a adição de bambolinas, que integradas como elementos aéreos do dispositivo cenográfico, estabeleciam os limites verticais do ambiente ou criavam ilusão de um espaço com amplitude muito maior do que o palco em si poderia acomodar.

Por outro lado, as bambolinas permitiam a inclusão de varas (de luz) horizontais, paralelas e acima do palco. Nessas varas - dispostas atrás das bambolinas eram instaladas velas de cera então consideradas mais seguras e eficientes, pois forneciam maior brilho com menor risco de incêndio. A atmosfera romântica exigia, ainda, um tratamento cromático da luz que apresentasse correspondência com a emoção veiculada em cena. Cada um desses passos apontava na direção do teatro realista, que provocaria desde o início do século XX a grande revolta da cena contra a ilusão, rendendo grandes mudanças na contribuição da luz.

O trabalho teórico do arquiteto francês Pierre Patte (1723-1814) ganha importância no trabalho de Surgers, quando ela comenta proposições realistas no 
teatro. Em seu Ensaio sobre a arquitetura teatral (Essai sur l'architecture théâtral, 1782), Patte aponta a impotência da cena pintada quando confrontada com a realidade. Na sua compreensão, comparada à multiplicidade de interações visuais entre o ser humano e o objeto real, à questão dos volumes e seus reflexos, a perspectiva mostra-se enfraquecida, revelando limitações, quando impõe ao observador a rigidez expressa nas relações entre o ponto de vista e o ponto de fuga. Surgers (2005b) amplia sua abordagem, mencionando inquietações que podem ser encontradas em Adolphe Appia. Mais de um século depois, Appia acentuou o conflito entre um ambiente pintado sob as regras da perspectiva e o corpo do ator, chamando a atenção para uma contradição implantada pelo teatro italiano, já no século XVI. A sugestão de volume na perspectiva era uma flagrante limitação denunciada pelas sombras pintadas em superfícies bidimensionais, na busca de "ilusão" tridimensional. (SURGERS, 2005b)

Na compreensão de Appia, um cenário composto de elementos bidimensionais pintados para criar a ilusão de tridimensionalidade torna-se alienado e falso, ao ser confrontado com o corpo vivo do ator. Numa relação de tal natureza, não somente o volume pintado, mas também o corpo do ator perde sentido e função, se o ambiente da cena pretende demonstrar unidade de tratamento. Juntamente com o ator, o ambiente da ação deveria apresentar também a tridimensionalidade; desse modo ficaria estabelecida uma relação "verdadeira". Apresentando volumes verdadeiros, "reais", objetivos, o ambiente não permitiria ao espectador dúvidas sobre a verdade espacial da cena, ele seria coagido pela "realidade absoluta" da qual o espetáculo estaria investido. Em tal contexto, portanto, a "verdade" não mantém nenhuma relação com o tratamento realista. Um dispositivo cenográfico tridimensional e abstrato ganha status de verdadeiro no diálogo formal, visual, espacial com o corpo do ator. Importante registrar que, sem a contribuição congruente da luz, tal qualidade não será revelada.

Desconsiderando tal contexto, a cena francesa do século XVIII "tratava" o ator, então, como uma superfície plana, chapada, sempre vista de frente: num certo sentido, se toda pintura é um produto artificial, o corpo do ator passava a ser artificializado para atender a convenção cenográfica. Tratava-se, por assim dizer, de uma convenção extrema, se consideramos que a cena, na sua condição de "corpo-espaço teatral", incorpora o corpo do ator como sua primeira célula tridimensional.

Tal abordagem compreende a cena como um acontecimento no qual o corpo do ator representa o primeiro corpo-espaço da ação. Por outro lado, o ator interage no teatro com diversificadas instâncias perceptivas e emocionais, resultando numa dilatação das funções da cena, em níveis que ampliam e também diversifi- 
cam seu caráter dimensional. Ou seja: a relação do espectador com o ator liberta-se da instância exclusivamente física, material, tridimensional. Transformando-se a cada gesto ou movimento, o corpo do ator gera inúmeras equações visuais "transdimensionais" em diretas relações com o ambiente.

A contradição principal apontada por Patte não parecia aproximar-se de qualquer solução, senão pela convenção já mencionada, que resolvia o problema tratando o ator como uma face plana, bidimensional. Surgers (2005b, p. 145, tradução nossa) destaca a questão:

A superioridade do volume 'natural' sobre o volume artificial da pintura ou do cenário de teatro está aqui aplicada em nome da semelhança com o 'natural'. Mas o argumento de Patte não poderia ter sucesso, pois o imitante (o volume), e o imitado (o natural ou a natureza), não passam de um só e mesmo fim [termo]. Patte chega a um impasse que só será resolvido um século mais tarde, graças às grandes revoluções da representação: na pintura, com o cubismo e o nascimento da arte abstrata e, no teatro, com Craig e Appia, e a invenção da. mise em scène. ${ }^{49}$

Como Surgers (2005b) acentua, o trabalho de Appia sugere uma direta relação entre a cenografia "ideal" - na qual o volume seja aspecto concreto - e a ilusão de realidade. Na segunda metade do século XVIII, a semelhança entre o real e aquilo que se vê tornou-se objetivo da representação teatral. A reforma do teatro Comédie Française representou importante passo dessa tendência.

Já foi mencionada aqui a crítica de Voltaire à ordem espacial do teatro francês do seu tempo. Surgers aponta o ataque de Voltaire à dramaturgia de Shakespeare, no qual ele usou adjetivos como monstruosa, qualificando negativamente a evocação de magia, a introdução de aparições, do sobrenatural, que deveriam ser banidos do teatro. Também os trabalhos de Diderot e Lavoisier, discutem tanto o real quanto o verdadeiro sob o prisma das imagens criadas em cena. Lavoisier mais particularmente interessado na aplicação da luz ao teatro. Voltando-se à sua contribuição pode-se destacar o interesse na exclusão da (luz de) ribalta que seria substituída por fontes de luz dispostas sobre o proscênio, e também nas suas laterais. Diz Lavoisier (1784, p. 96, tradução nossa): "[...] uma [luz do] dia que atinge o corpo de baixo para

49 “La supériorité du volume 'naturel' sur le volume fictif de la peinture ou de décor de théâtre est ici affirmée au nom de la ressemblance au 'naturel'. Mais le raisonnement de Patte ne pouvait aboutir, pluis que l'imitant (le volume) et l'imitér (le naturel ou la nature) n'y son qu'un seul et même terme. Patte arrivait donc à une impasse, qui s'est ouverte environ un siècle plus tard, grâce aux grandes revolutions de la reprèsentation: en peinture avec le cubisme e la naisssance de l'art abstrait et, pour le théâtre avec Craig et Appia et l'invention de la mise en scène." 
cima não é a mais natural, uma vez que ela reverte a ordem das sombras e da luz, uma vez que ela distorce, até certo ponto, a fisionomia dos atores". ${ }^{0}$

Apesar da sua opinião sobre as impropriedades da ribalta, Lavoisier (1784) afirma que a luz disponível àquele momento nos teatros, fossem lamparinas a óleo ou velas, seria insuficiente para iluminar os atores, se dispostas nas laterais ou acima do proscênio: a luz lateral produzia luminosidade deficiente no centro do proscênio; instrumentos localizados acima, em relação perpendicular com essa área de atuação, projetavam sombras próprias indesejadas no corpo do ator, nos olhos, sobre a parte baixa do rosto e faziam aparecer as menores rugas e imperfeições da pele. A perpendicularidade das fontes de luz instaladas acima da cabeça transformaria o ator em obstáculos, cujas sombras se projetariam sobre seu próprio corpo. Nos momentos mais trágicos (importantes) essas sombras o fariam "escapar visualmente", por assim dizer, aos espectadores. Na opinião de Lavoisier (1784, p. 96, tradução nossa), ${ }^{51}$ tal conjunto de resultados representaria, "[...] o mais desagradável de todos os efeitos [...]". ${ }^{2}$

Note-se a importância da qualidade "natural" (ou real) que começava a se impor manifestando-se em diversas instâncias da atividade teatral. Surgers (2005b) acentua Beaumarchais, [Pierre-Augustin Caron de Beaumarchais (1732-1799)], comentando a rubrica de abertura de "Le mariage de Figaro", citada a seguir:

O palco representa uma sala semidesmobiliada, uma grande cadeira para doentes [uma poltrona de dimensões especiais] ao centro. Fígaro, com uma toesa [antigo instrumento francês para medir], mede o piso. Suzanne está diante de um espelho e põe à cabeça um pequeno buquê de flores de laranjeira, chamado chapéu de noiva. ${ }^{53}$ (BEAUMARCHAIS, 1934, p. 48, tradução nossa)

\footnotetext{
50 “[...] un jour qui frappe le corps de bas en haut n'est pas le plus naturel, qu'il renverse l'ordre des ombres et des clairs, qu'il démonte même, si l'on veut, jusqu'à un certain point la physionomie des acteurs; [...]

51 No trabalho de Lavoisier podem ser encontradas indicações técnicas que ele considerava solução de parte destes problemas, como se observa na sua proposição para que adicione superfícies refletoras (réverbères) às fontes de luz, o que resultaria em duas grandes vantagens: ampliação do brilho projetado sobre a cena e controle da direção da luz, quando planejada em conjunto com a disposição das "varas" fora do palco [próximas ao proscênio] Aqueles interessados na aplicação da ótica aos instrumentos concebidos para produzir luz na cena, podem encontrar neste trabalho de Lavoisier material importante para estudo, incluindo a avalição das superfícies refletoras de natureza esferoide-elíptica neste contexto.

52 "les plus désegréable de tous les effets, [...]."

53 "Le théâtre représente une chambre à demi démeublée; un grand fauteuil de malade est au milieu. Figaro, avec une toise, mesure le plancher. Suzanne attache à sa tête, devant une glace, le petit bouquet de fleurs d'orange, appelé chapeau de la mariée. [O móvel ao centro é a poltrona na qual o Cherubino se esconderá no curso da ação]."
} 
De acordo com Surgers (2005b) essa rubrica é a primeira na instalação da dramaturgia denominada burguesa; é importante notar a descrição de um único ambiente no interior de um edifício, assim como a ação "natural", incluindo a localização das personagens. Trata-se de um exemplo que demonstra o caminho da dramaturgia em direção ao realismo que se fortaleceria mais tarde. Para experimentar emoções profundas, o público precisava reconhecer o ser humano em cena, assim como o seu ambiente. Tomando parte no contexto, estudiosos do espaço teatral avaliaram a contribuição da luz para o movimento em curso.

A segunda metade do século XVIII trouxe outros estudos ligados à visualidade da cena, a despeito de diferentes abordagens. Destaque-se, no interesse da investigação em andamento, Ensaio sobre a ópera (Essai sur l'opéra), 1755, de Francesco Algarotti (1712-1764); Cartas sobre a dança (Lettres sur la dance), 1760, de Jean-Georges Noverre (1727-1810); O projeto de uma sala de espetáculos (Le project d'une salle de spetacles), 1765, de Charles-Nicholas Cochin (1715-179o); Tratado da construção de teatros e máquinas teatrais (Traité de la construction des théâtres et des machines théâtrales), (1777), de André-Jacob Roubo (1739-1791); Observações sobre a construção de uma sala de espetáculos (Observations sur le construction d'une salle de spetacles), 1781, também de Noverre. Ainda que, de "lugares" diferentes, cada um deles se refere à luz, estabelecendo uma possibilidade de reflexão sobre o espetáculo motivada pelas suas manifestações visuais.

A obra de Noverre interessa, antes de tudo, ao artista envolvido com a práxis cênica em si, e não exclusivamente aos pesquisadores da dança. Um jovem diretor em formação encontrará nesses escritos vigorosas provocações que levaram o "Compositeur" ou "Mâitre de Ballet" (como ele chama o responsável pelos espetáculos de dança), a discutir novos princípios para a dança, incluindo aspectos da sua teatralidade e do seu caráter visual.

Já no início da primeira carta, Noverre (1760, p. 1, tradução nossa) dispõe uma assertiva que integra a orientação de suas proposições acerca da dança: "A Poesia, a Pintura e a Dança não são, Senhor, ou não devem ser, mais que uma cópia fiel da bela natureza; é pela verdade dessa imitação que as obras de artistas como Racine e Raphael passarão à posteridade [...]".54

Ele aplicará, em outros momentos, os termos cópia e imitação, como sinônimos, aliando características que, em sua opinião, seriam imprescindíveis aos novos caminhos da dança, que ele chama danse en action ou ballet en action. Tal ligação da dança com a "ação" se daria pela alocação dos sentimentos, ou seja, pela inclu-

54 "La poésie, la peinture et la danse ne son, Monsieur, ou ne doivent être qu'une copie fidelle de la belle nature: c'est par la verité de cette imitation que les Ouvrages de Racine, de Raphaël ont passé à la posterité; [...]." 
são de personagens e, portanto, de desejos humanos, incorporando e mesclando a natureza e elementos do drama. Noverre reconhece o alto grau de dificuldade então enfrentado por um Maître de Ballet ou Compositeur, uma vez que, na elaboração estética, visual, desses espetáculos, o artista não tem à sua disposição instrumentos (como pincéis ou espátulas), ou materiais, como tintas. Ele deve produzir através da arte dos gestos e da pantomima quadros diversificados que durarão apenas alguns instantes, sucedendo-se uns aos outros. Trata-se de um novo caminho para a dança, espetáculos que buscam ligações com a história, com a poesia e com a pintura, para alcançar mais que a possibilidade de agradar aos olhos. Uma pintura que só se pode alcançar na cena, capaz de revelar imagens - quadros, pinturas - em movimento, que se sucedem até o final do espetáculo.

Ele acreditava que, incorporando elementos do teatro, a dança podia cativar o espectador através do encantamento da mais perfeita ilusão, falando-lhe à alma. Criticando a dança do seu tempo, Noverre (1760, p. 6, grifo e tradução nossos) aponta novos rumos: "[...] a maioria dos compositeurs sacrificam a beleza da Dança e abandonam a graça ingênua do sentimento [...]".55 Ao mencionar o sentimento, a emoção, ele se refere (positivamente) aos traços teatrais que deseja ver incorporados à dança.

Compreendendo a práxis cênica como um empreendimento visual, ele comentou:

Seria necessário que os Maîtres de Ballets consultassem os quadros dos grandes pintores: este exame os aproximaria, sem dúvida, da natureza; eles evitariam então, tanto quanto fosse possível, a simetria nas figuras que, pela repetição do objeto, oferece, na mesma tela, dois quadros semelhantes. ${ }^{56}$ (NOVERRE, 1760, p. 7, grifo e tradução nossos)

Noverre procurava aliar o inesperado que se encontra tanto na natureza quanto na obra de grandes pintores (e que deve resultar na retirada de arranjos simétricos do palco), com elementos do drama, como paixões e emoções, para incorporar à dança qualidades que ele compreendia como inerentes à ação cênica. A simetria tornava-se um grande perigo para a danse en action ou o ballet em action. O uso exagerado das disposições simétricas tinha, para Noverre, o resultado nocivo de afastar a dança da vida. Aliás, em sua opinião, o abuso recorrente - mesmo dos melhores elementos -

55 “[...] les plus grand nombre des Compositeurs sacrifient les beautés de la Danse, \& abandonnent les graces naîves du sentiment, [...]."

56 "Il faudroit que les Maîtres de Ballets consultassent les Tableux des grands Peintres: cet examen les rapprocheroit sans doute de la nature; ils éviteroitent alors, le plus souvent qu'íl leur seroit possible, cette symmétrie dans les figures qui, faisant répétition d’bjet, offre sur la même toile deux Tableaux semblables." 
seria sempre nocivo. Ou seja: a repetição artificializaria (num sentido negativo), estabelecendo fórmulas. Para ele, um artista sem inteligência e sem (bom) gosto trata mecanicamente sua dança, privando-a do efeito (natural), distanciando-a do espírito; Noverre, então, indica o que se deve buscar:

Uma Scène d'action, na qual a Dança deve falar com calor, com energia: onde as figuras simétricas e afetadas não podem ser empregadas sem alterar a verdade, sem entrar em choque com a verossimilhança, sem enfraquecer a ação e afastar o interesse. ${ }^{57}$ (NOVERRE, 1760, p. 9-10, grifo e tradução nossos)

Para nomear a categoria de espetáculo que procurava, ele aplica expressões como scène d'action, danse em action ou ainda ballet en action, com a intenção de aproximar sua dança do drama e da pintura, responsáveis pelo que ele considera belo, verdadeiro, voltando-se para o gesto que ele classifica natural, acentuando a qualidade visual dessa manifestação artística:

O Balé bem composto é uma Pintura viva das paixões, do comportamento, do uso, das cerimônias e dos costumes de todos os povos da terra: consequentemente, ele deverá incluir todos os gêneros da Pantomima e falar à alma, pelo olhar. ${ }^{58}$ (NOVERRE, 1760, p. 18, tradução nossa)

Para falar à alma, a dança deveria incorporar as paixões do drama e, para criar características "reais" e ou "verdadeiras", a simetria deveria ser banida. A aparência de verdade que resultaria do tratamento assimétrico do espaço emprestaria aos espetáculos a qualidade de ação cênica. O olhar treinado de um designer vislumbraria um projeto de luz que respondesse às exigências de proposições dessa natureza, cujas indicações de ângulos, cores e texturas são muito particulares. Ele desaprovaria a estratégia mecânica que ainda hoje se repete em muitos espetáculos nos quais o palco é dividido ao meio e o projeto de luz resume-se à distribuição simétrica dos instrumentos (refletores). Quanto maior o orçamento, mais "combinações" gráficas, geralmente simétricas. Isso pode ser facilmente compreendido quando se observa a simetria como uma zona de conforto: se o orçamento do espetáculo só comporta 50 instrumentos, basta decidir que cada um dos lados do

57 “[...] une Scène d'action, où la Danse doit parler avec feu, avec energie: où les figures symmétriques \& compassées ne peuvent être employées sans altérer la verité, sans choquer la vraisemblance, sans assoiblir l'action \& refroidir l'interêt."

58 "Le Ballet bien composé est une Peinture vivante des passions, des mouers, des usages, des ceremonies, \& du costume de tous les Peuples de la terre; conséquemment, il doit être Pantomime dans tous les genres, \& parler à l'ame par les yeux." 
palco contará com 25. Se, no entanto, o número total for elevado para 500, os 25 transformam-se em 250.

Difícil errar numa operação meramente aritmética e tão simples. O trabalho de um designer, no entanto, pode alcançar outras esferas visuais. A crítica à simetria já aponta para uma disposição dos instrumentos não encontrada nos teatros franceses do período. O tratamento da visualidade, presente na ideia de espetáculo que Noverre (1760) defende, aponta para uma qualidade cromática específica. A nova dança exigia uma imagem viva.

O pensamento da cena francesa em direção aos pressupostos do realismo, também aqui podem ser aliados à ideia da cena como um "quadro vivo" (tableau vivant), ou uma sucessão de quadros vivos, revelando a verdade, o real, e reconhecendo no artista responsável pela cena, um pintor. Sua cumplicidade com a luz parece, então, inevitável. Mais uma vez pode-se citar Diderot e lembrar sua correspondência com Mme. Riccoboni. ${ }^{59}$ Ela envia uma carta a Diderot, provavelmente em 1758, na qual questiona sua teoria do espetáculo, baseando os comentários no texto teórico que acompanha Le pére de famille, escrito por Diderot no mesmo ano.

Na sua carta, Mme. Riccoboni defendeu com veemência o trabalho do ator e enfatizou o valor da experiência no palco, para a compreensão da cena. A abordagem teórica de Diderot estava fundamentada no seu próprio exercício literário, assim como no seu interesse e curiosidade sobre o funcionamento do espetáculo. Interesse, aliás, também manifestado pela correspondente. No particular, despertava a atenção do leitor para a importância da visualidade, tanto numa abordagem, quanto noutra. Defendendo, de modo veemente, seu ponto de vista, ela criticou Diderot: "O teatro é uma imagem, concordo. Mas uma imagem em movimento, da qual não temos tempo para examinar os detalhes". ${ }^{60}$ (RICCOBONI apud DIDEROT, 1875, p. 396, tradução nossa)

Ao retrucar, numa carta enviada no mesmo ano, Diderot (1875) acentuou as relações entre a dramaturgia e a visualidade da cena, apontando a importância estratégica de certos momentos para as afirmações visuais de um espetáculo. Ele argumentou: "Não [teremos dificuldade em observar os detalhes visuais] no primeiro momento [do espetáculo], quando se levanta a cortina. Então, se há

59 Marie Laboras Mézières (1714-1792), mais tarde conhecida como Mme. Riccoboni, depois do seu casamento, em 1734, com Antonio Francesco Riccoboni, filho de Luigi Riccoboni, importante ator da Comédie Italienne e autor de Da arte da representação [Dell'arte rappresentativa (1728)] e Pensamentos sobre a declamação [Pensées sur la déclamation (1738)]. Ingressando numa família de renomados artistas, ela mesma estreia como atriz um mês depois de casar-se. Ela permanece na profissão por quase trinta anos quando, em 1631, decide dedicar-se à carreira literária. 60 "Le théâtre est un tableau, d'accord; mais c'est un tableau mouvant dont on n'a pas le temps d'examiner les details." 
silêncio entre as personagens, meu olhar se detém sobre seus movimentos e não perderei nada". ${ }^{61}$ (DIDEROT, 1875, p. 398-399, tradução nossa)

Diderot (1875) incluiu uma crítica ao posicionamento dos atores em cena, sempre de frente, dispostos num semicírculo em relação ao proscênio e à luz de ribalta. Baseando-se na sua compreensão de atriz, sua correspondente invocou o papel da percepção visual para a relação com o público, na qual, um pequeno gesto ou expressão teria função importante, argumentando: "[...] a três pés da ribalta um ator fica sem rosto". 62 (RICCOBONI apud DIDEROT, 1875, p. 396, tradução nossa) E, no que se refere à verossimilhança, Mme. Riccoboni revelou sua compreensão da cena como uma convenção, um processo seletivo de artificialização que permitia alcançar a ilusão desejada na cena: "A natureza é bela, mas é preciso que a vejamos por ângulos capazes de torna-la útil e agradável [...] A cena não pode jamais ser tão simples como um quarto [de dormir]; e, para que algo seja verdadeiro no teatro, deve ser um pouco mais que natural [real]".63 (RICCOBONI apud DIDEROT, 1875, p. 397, tradução nossa)

As assertivas de Mme. Riccoboni são relevantes para a compreensão do tratamento realista que se desenvolverá no teatro, no século seguinte. Ou seja, resumir, de modo simplório, que essa estética não passa de cópia da realidade, de ilusionismo, pode resultar numa compreensão do realismo como algo fácil, sem fundamentação ou função, um tratamento generalizado, e até preguiçoso, do espaço da cena. A atriz e autora Mme. Riccoboni enfatiza as características de convenção, que exigem atenção e muito trabalho do artista.

No quesito ilusão, à medida que novas tecnologias foram incorporadas à práxis cênica, mais se tornou possível efetivar o realismo na cena. Simultaneamente, a exigência dirigida ao artista que pretendia apresentar um tratamento realista do espetáculo era ampliada. Isso se justifica, pois, tendo à sua disposição instrumentos, acessórios, sistemas de controle, literatura, e a experiência de espectador, ele terá a obrigação de levar à cena resultados convincentes. Resultados que apontem mais para as relações entre a tecnologia disponível e a convenção realista propriamente dita, do que para a expectativa do senso comum. Além disso, não se pode esperar da crítica e do público conhecimento e vontade para avaliar métodos e/

\footnotetext{
61 "Ce n'est pas dans un premier mornent, au lever de la toile. Alors, s'il règne du silence entre les personnages, mes regards se répandront sur leurs mouvements et je n'en perdrai rien."

62 "[...] qu'à trois pieds des lampes un acteur n'a plus de visage."

63 "La nature est belle, mais il faut la montrer par les côtés qui peuvent la rendre utile et agréable. [...] La scène ne peut jamais devenir aussi simple que la chambre; et, pour être vrai au théâtre, il faut passer un peu le naturel."
} 
ou procedimentos específicos, quando até mesmo os resultados não são corretamente avaliados.

É possível observar na breve correspondência entre Mme. Riccoboni e Diderot o flagrante interesse pelas implicações visuais do espetáculo, mesmo em dois artistas com enfoques diversificados. Bom seria encontrarmos ainda hoje autores, diretores e dramaturgos seriamente interessados na discussão. 